Central Washington University

ScholarWorks@CWU

$1-2021$

Carbonaceous matter in the atmosphere and glaciers of the Himalayas and the Tibetan plateau: An investigative review

Chaoliu Li

Fangping Yan

Shichang Kang

Caiqing Yan

Zhaofu Hu

See next page for additional authors

Follow this and additional works at: https://digitalcommons.cwu.edu/geological_sciences

Part of the Atmospheric Sciences Commons, Environmental Indicators and Impact Assessment Commons, and the Glaciology Commons 
Authors

Chaoliu Li, Fangping Yan, Shichang Kang, Caiqing Yan, Zhaofu Hu, Pengfei Chen, Shaopeng Gao, Chao Zhang, Cenlin He, Susan Kaspari, and Aron Stubbins 
Review article

\title{
Carbonaceous matter in the atmosphere and glaciers of the Himalayas and the Tibetan plateau: An investigative review
}

\author{
Chaoliu Li ${ }^{\text {a,b,d,* }}$ Fangping Yan ${ }^{\text {b,c }}$, Shichang Kang ${ }^{\text {b, d,e }}$, Caiqing Yan ${ }^{\mathrm{f}}$, Zhaofu Hu ${ }^{\text {b,e }}$, \\ Pengfei Chen ${ }^{\mathrm{b}}$, Shaopeng Gao ${ }^{\mathrm{a}}$, Chao Zhang ${ }^{\mathrm{a}, \mathrm{e}}$, Cenlin $\mathrm{He}^{\mathrm{g}}$, Susan Kaspari ${ }^{\mathrm{h}}$, Aron Stubbins ${ }^{\mathrm{i}}$ \\ ${ }^{a}$ CAS Key Laboratory of Tibetan Environment Changes and Land Surface Processes, Institute of Tibetan Plateau Research, Chinese Academy of Sciences, Beijing 100101, \\ China \\ b State Key Laboratory of Cryospheric Science, Northwest Institute of Eco-Environment and Resources, Chinese Academy of Sciences, Lanzhou 730000, China \\ ${ }^{c}$ UT School of Engineering Science, Lappeenranta University of Technology, P.O. Box 20, 53851 Lappeenranta, Finland \\ ${ }^{d}$ CAS Center for Excellence in Tibetan Plateau Earth Sciences, Chinese Academy of Sciences, Beijing 100101, China \\ ${ }^{\mathrm{e}}$ University of Chinese Academy of Sciences, Beijing 100049, China \\ ${ }^{\mathrm{f}}$ Environment Research Institute, Shandong University, Qingdao 266237, China \\ ${ }^{\mathrm{g}}$ Research Applications Laboratory, National Center for Atmospheric Research, Boulder, CO 80301, USA \\ ${ }^{\mathrm{h}}$ Department of Geological Sciences, Central Washington University, Ellensburg, WA 98926, USA \\ ${ }^{\mathrm{i}}$ Departments of Marine and Environmental Science, Chemistry and Chemical Biology, and Civil and Environmental Engineering, Northeastern University, Boston, MA \\ 02115, USA
}

\section{A R T I C L E I N F O}

Handling Editor: Xavier Querol

\section{Keywords:}

Tibetan Plateau

Black carbon

Organic carbon

Local emissions

Light absorption

Deposition

\begin{abstract}
A B S T R A C T
Carbonaceous matter, including organic carbon (OC) and black carbon (BC), is an important climate forcing agent and contributes to glacier retreat in the Himalayas and the Tibetan Plateau (HTP). The HTP - the so-called "Third Pole" - contains the most extensive glacial area outside of the polar regions. Considerable research on carbonaceous matter in the HTP has been conducted, although this research has been challenging due to the complex terrain and strong spatiotemporal heterogeneity of carbonaceous matter in the HTP. A comprehensive investigation of published atmospheric and snow data for HTP carbonaceous matter concentration, deposition and light absorption is presented, including how these factors vary with time and other parameters. Carbonaceous matter concentrations in the atmosphere and glaciers of the HTP are found to be low. Analysis of waterinsoluable organic carbon and BC from snowpits reveals that concentrations of OC and BC in the atmosphere and glacier samples in arid regions of the HTP may be overestimated due to contributions from inorganic carbon in mineral dust. Due to the remote nature of the HTP, carbonaceous matter found in the HTP has generally been transported from outside the HTP (e.g., South Asia), although local HTP emissions may also be important at some sites. This review provides essential data and a synthesis of current thinking for studies on atmospheric transport modeling and radiative forcing of carbonaceous matter in the HTP.
\end{abstract}

\section{Introduction}

Carbonaceous aerosols, including organic carbon (OC) and black carbon (BC), play an important role in the climate system. Carbonaceous particles deposited on snow and ice surfaces are referred to as carbonaceous matter, which can be classified into $\mathrm{BC}$, water-insoluble organic carbon (WIOC) and water-soluble organic carbon (WSOC; the equivalent of dissolved organic carbon (DOC) in aerosol studies) (Li et al., 2016c).

$\mathrm{BC}$ warms the atmosphere and is the second most important warming component after $\mathrm{CO}_{2}$ in the atmosphere (Bond et al., 2013; Ramanathan and Carmichael, 2008). Light absorption by BC is evaluated by the mass absorption cross section (MAC) of $\mathrm{BC}\left(\mathrm{MAC}_{\mathrm{BC}}\right.$ ) (Bond and Bergstrom, 2006). The measured $M A C_{B C}$ value for uncoated $B C$ particles is $7.5 \pm$ $1.2 \mathrm{~m}^{2} \mathrm{~g}^{-1}$ at $550 \mathrm{~nm}$ (Bond and Bergstrom, 2006). Generally, the MAC $_{\mathrm{BC}}$ increases quickly after $\mathrm{BC}$ is emitted from combustion activities (Gustafsson and Ramanathan, 2016).

OC has a net negative radiative forcing and generally causes cooling (IPCC, 2013). However, colored organic matter, also referred to as

\footnotetext{
* Corresponding author at: CAS Key Laboratory of Tibetan Environment Changes and Land Surface Processes, Institute of Tibetan Plateau Research, Chinese Academy of Sciences, Beijing 100101, China.

E-mail address: lichaoliu@itpcas.ac.cn (C. Li).
} 
brown carbon (BrC), also absorbs sunlight and warms the atmosphere (e. g., Andreae and Gelencser, 2006; Saleh et al., 2014; Yan et al., 2015). In contrast to BC, light absorption by BrC shows a strong spectral dependence, with stronger absorption at shorter (ultraviolet) wavelengths (Helms et al., 2008). As BrC is defined by its color, not the concentration of a specific compound or class of compounds, $\mathrm{BrC}$ concentrations cannot be measured. Instead, the optical properties of $\mathrm{BrC}$ or $\mathrm{OC}$ are reported. Generally, the light absorption of $\mathrm{OC}$ is evaluated as $\mathrm{MAC}_{\mathrm{OC}}$, which can be divided into $\mathrm{MAC}_{\mathrm{WIOC}}$ and $\mathrm{MAC}_{\mathrm{WSOC}}$. $\mathrm{MAC}_{\mathrm{WIOC}}$ is commonly higher than MAC Wsoc (Chen and Bond, 2010). For instance, $\mathrm{MAC}_{\text {WIOC }}$ and $\mathrm{MAC}_{\mathrm{WSOC}}$ of $\mathrm{PM}_{2.5}$ (particulate matter with an aerodynamic diameter below $2.5 \mu \mathrm{m}$ ) in winter in Beijing were $1.66 \pm 0.48$ $\mathrm{m}^{2} \mathrm{~g}^{-1}$ and $1.22 \pm 0.11 \mathrm{~m}^{2} \mathrm{~g}^{-1}$, respectively (Cheng et al., 2016).

After deposition on snow and ice, these light-absorbing components can further absorb sunlight and reduce snow and ice albedo, which accelerates the melting of snowpack and glaciers and can result in significant climatic and environmental consequences (Lau et al., 2006; Qian et al., 2011). Constraining concentrations of BC and OC in the atmosphere and snow/ice is challenging due to the complex nature and large spatial variations of carbonaceous matter. For instance, both OC and BC are composed of multiple components and often mixed together, so that no optimal method exists for accurately determining $\mathrm{OC}$ and $\mathrm{BC}$ concentrations (Andreae and Gelencser, 2006). Meanwhile, as for some other short-lived species in the atmosphere, carbonaceous particles are often strongly concentrated around emission sources (Bond et al., 2013). Therefore, the abovementioned factors contribute to uncertainties in both estimated concentrations of carbonaceous matter and their transport, deposition, and radiative forcing. Such uncertainties are more pronounced for remote areas with harsh environments, particularly over glaciers, where it is hard to conduct in situ measurements.

The Himalayas and the Tibetan Plateau (HTP) is a remote region that has low levels of local human activity and is physically distant from regions with major emissions. The HTP is also characterized by the most extensive glacier area and snow and ice masses outside the Arctic and Antarctic. Therefore, the HTP is also referred to as the Third Pole (Yao et al., 2012) and is susceptible to environmental change due to regional and global warming. Carbonaceous particles may be an important trigger of glacial retreat in this fragile region (He et al., 2018; Xu et al., 2009), potentially affecting the seasonal supply of freshwater to billions of residents downstream (e.g., Kang et al., 2019; Kang et al., 2020; Lau et al., 2010; Menon et al., 2010; Xu et al., 2016; Zhang et al., 2017b). It is estimated that the surface radiative forcing due to BC-induced snow albedo reduction has been above $5 \mathrm{~W} \mathrm{~m}^{-2}$ during spring and summer in many areas of the HTP (He et al., 2018; Kopacz et al., 2011; Qian et al.,
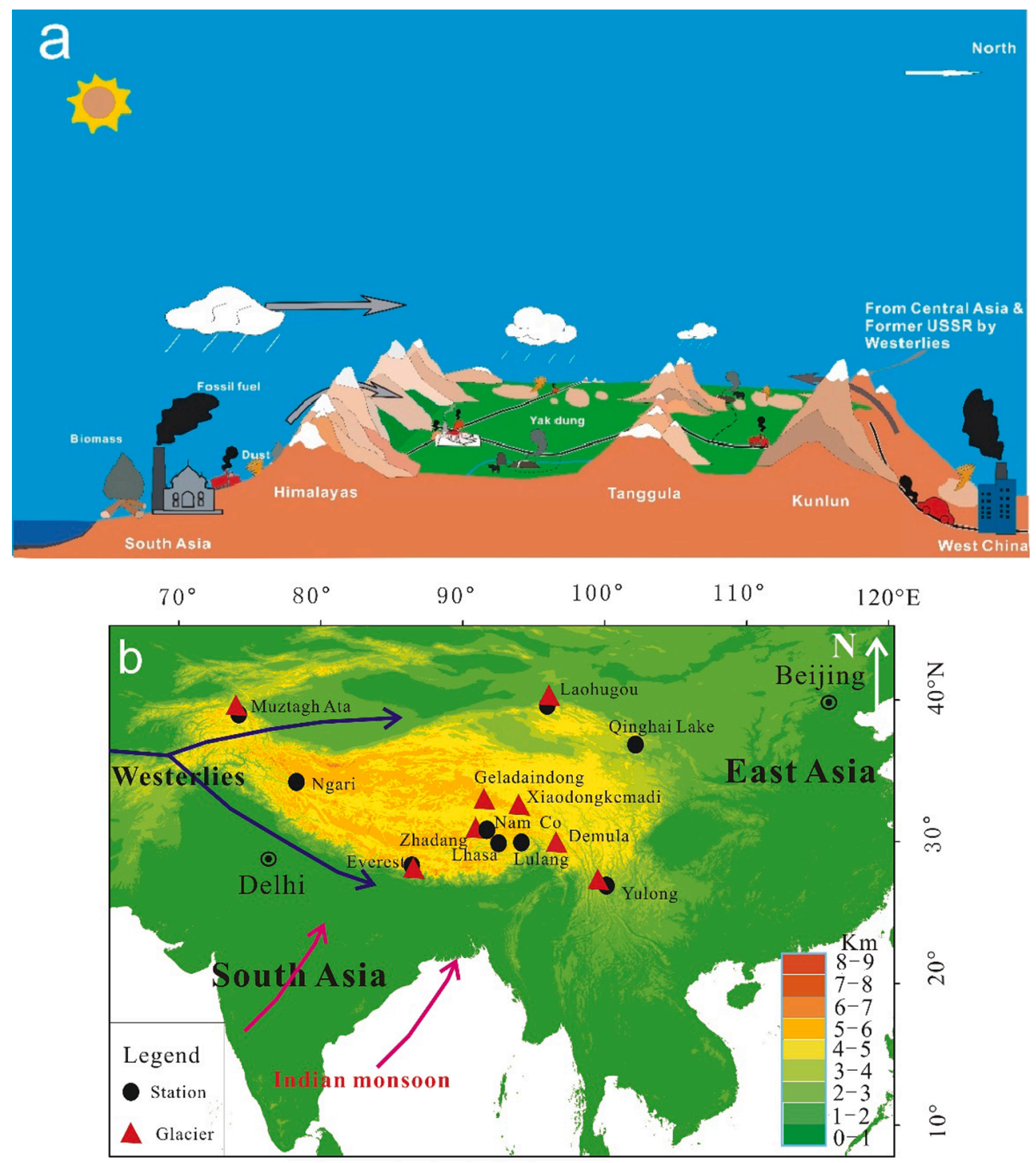

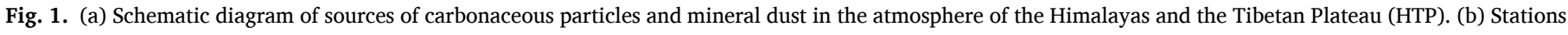
and glaciers studied in this review. 
2011).

Thus, an increasing number of studies have focused on carbonaceous particles, especially BC in the HTP atmosphere and glaciers. In particular, interest in this subject was boosted after the discovery of Asian Brown Clouds and the associated climate consequences (Ramanathan et al., 2001). Subsequently, numerous studies on carbonaceous particles were conducted in the Indian subcontinent (e.g., Bikkina et al., 2019; Sheesley et al., 2003), the western Himalayas (e.g., Pant et al., 2006; Ram et al., 2010) and the Central Himalayas (e.g., Decesari et al., 2010; Kaspari et al., 2014; Marinoni et al., 2010; Ming et al., 2008).

However, the knowledge of carbonaceous particles and their climatic effects over the HTP is still limited, and monitoring stations are rather sparsely distributed across the large HTP areas despite research advancements (Fig. 1, Fig. S1). Most stations and field campaign measurements are primarily distributed in the southern and eastern regions of the HTP, thus preventing accurate estimates of carbonaceous particles and their radiative/climatic effects over the entire HTP. Meanwhile, large uncertainties exist in previously reported measurement data. For instance, high atmospheric mineral dust concentrations in some regions of the HTP cause potential bias in carbonaceous particle measurements. It has been reported that $\mathrm{BC}$ concentrations in total suspended particles (TSP) at Nam Co and Everest stations, two typical remote stations in the middle and southern parts of the HTP, were overestimated by $52 \pm 35 \%$ and $39 \pm 24 \%$, respectively, due to contributions of inorganic carbon (e. g., carbonate) in mineral dust (Li et al., 2017a). Similarly, OC concentrations were overestimated by $22 \pm 10 \%$ and $22 \pm 12 \%$, respectively, at these two stations ( $\mathrm{Li}$ et al., 2017a). However, the contribution of inorganic carbon should be low in the southeast HTP with high forest coverage, as suggested in a previous study (Chow and Watson, 2002). In addition, mineral dust is also an important component of light-absorbing impurities in glaciers of the HTP, especially in aged snow (snow that has experienced thaw-freeze cycles) and bare ice (Li et al., 2017c; Qu et al., 2014). It should be noted that several published studies have ignored the influence of inorganic carbon in mineral dust in the HTP (e.g., Li et al., 2017c; Niu et al., 2018; Qu et al., 2014; Zhang et al., 2017b), thus overestimating OC and BC concentrations in those glaciers. Therefore, it is essential to correct this measurement bias and build an improved dataset for $\mathrm{OC}$ and $\mathrm{BC}$ concentrations in the atmosphere and glaciers of the HTP to provide better reference data for related studies. OC and BC ratios between acid-treated and untreated aerosol samples can be adapted to remove the influence of inorganic carbon on $\mathrm{OC}$ and $\mathrm{BC}$ values for snow/ice samples of glaciers.

Furthermore, although South Asia is generally considered the main source of BC in the HTP (e.g., Cong et al., 2015; Lin et al., 2017; Ming et al., 2010; Zhao et al., 2013b), recent studies have indicated that local emissions from the Tibetan Plateau are also significant at certain sites (Hu et al., 2018a; Li et al., 2016a; Li et al., 2018b). Therefore, previously reported in situ data and conclusions need to be critically investigated and constrained. This would allow a better understanding of the status of carbonaceous particles in the HTP and provide better reference values for studies focusing on radiative forcing estimates and modeling (Chung et al., 2012; He et al., 2014). After considering potential influencing factors, this review seeks to provide an improved/corrected database of the concentrations, compositions, deposition, and light-absorbing properties of carbonaceous matter in the HTP, which thus distinguishes this review from previous studies (e.g., Gertler et al., 2016; Ming et al., 2013; Yan et al., 2018; Zhang and Kang, 2017).

In this review, in situ observational data have been utilized to elucidate several fundamental characteristics of carbonaceous particles, including concentrations; relative ratios among WIOC, BC, and WSOC; light absorption characteristics; deposition; and sources of the abovementioned components in the atmosphere and glaciers of the HTP.

Characteristics of carbonaceous matter in glacier regions in the HTP can be investigated by collecting snow samples from snowpits in the accumulation zone of glaciers in spring before the onset of snowmelt ( $\mathrm{Li}$ et al., 2016a; Ming et al., 2013). By sampling snowpits from the surface of the snowpack down to the last autumn layer prior to spring melt, the collected samples preserve direct atmospheric deposition of carbonaceous particles in the snowpack, with minimal melt influence during winter and spring. This provides a valuable view of the original distribution of impurities within snow without considering post-depositional processes. Although carbonaceous matter in the ablation zone (e.g., in cryoconites) is also important for snow/ice albedo reduction (e.g., Cook et al., 2016; Li et al., 2017c; Takeuchi, 2002), substantial postdepositional processes make it challenging to study the direct connection between ablation-zone carbonaceous particle concentration and atmospheric deposition. Therefore, this review focuses primarily on snowpit data. This review yields an improved understanding of this topic and can be utilized by future studies, especially those focusing on modeling. Finally, a perspective on promising future research directions is presented.

\section{Methodology}

In this review, previously published carbonaceous matter data from the atmosphere and on glaciers across the HTP are synthesized and discussed. The sampling and measurement methods for the main particle characteristics/quantities are described in detail in Text S1 (see the supporting information). The reported data were corrected by accounting for factors such as the influence of different measurement methods and the contribution of inorganic carbon in mineral dust to reduce uncertainties (Table 1). First, data from NIOSH 5040 were adjusted to those of IMPROVE-A based on the $\mathrm{BC}_{\text {IMPROVE-A TOR }} / \mathrm{BC}_{\mathrm{NIOSH}}$ 5040 тот ratio (1.32 \pm 0.74 ) (Li et al., 2017a). Second, data from original samples were adjusted to the values for acid-treated samples according to $\mathrm{OC}_{\text {acid-treated }} / \mathrm{OC}_{\text {original sample }}(0.78 \pm 0.12)$ and $\mathrm{BC}_{\text {acid-treated }} / \mathrm{BC}_{\text {original }}$ sample $(0.61 \pm 0.24)$ ratios for TSP collected at the Everest station (Li et al., 2017a). At present, BC concentrations in the atmosphere of the HTP are typically measured by either the thermal-optical method (Cao et al., 2009; Ming et al., 2010) or aethalometers (Zhang et al., 2017a; Zhao et al., 2017). BC is normally referred to as elemental carbon (EC) when measured with the thermal-optical method (Petzold et al., 2013). $\mathrm{BC}$ concentrations reported from aethalometers are called equivalent black carbon (eBC) (Petzold et al., 2013) and are generally comparable to or higher than those obtained from thermal-optical methods based on aerosol samples untreated by acid (Ming et al., 2010; Zhang et al., 2017a). One of the shortcomings of measuring BC with an aethalometer is that it cannot measure OC concentration simultaneously. BC concentrations in glacier snow/ice samples over the HTP are measured mainly by the thermal-optical method (e.g., Li et al., 2016a; Qu et al., 2014; Xu et al., 2009; Zhang et al., 2017b).

\section{Distributions, sources and properties of carbonaceous matter in the HTP}

\subsection{Carbonaceous particle concentrations and compositions}

\subsubsection{Carbonaceous particles in the surface air}

Concentrations of carbonaceous particles in the atmosphere are fundamental to understanding their sources, transport, deposition, and radiative forcing. Lhasa is the second largest city in the HTP (Fig. S2). The annual average $\mathrm{OC}$ and $\mathrm{BC}$ concentrations in $\mathrm{PM}_{2.5}$ samples in the ambient atmosphere of Lhasa have been reported as 3.27 and $2.24 \mu \mathrm{g}$ $\mathrm{m}^{-3}$, respectively (Li et al., 2016b), which are approximately 0.22 and 0.26 times those in Beijing, respectively (Cheng et al., 2011). Concentrations and compositions of carbonaceous particles measured at remote stations of the HTP can be used as reference data in atmospheric transport models (Ji et al., 2015; Zhang et al., 2015a) and are also crucial for investigating deposition and light absorption properties of carbonaceous matter in glaciers. Previous studies (Cong et al., 2015; Ming et al., 2010; Zhao et al., 2013a; Zhao et al., 2013b) have reported relatively high $\mathrm{BC}$ concentrations (e.g., $320 \mathrm{ng} \mathrm{m}^{-3}$ at Lulang station) at 
Table 1

Original and adjusted concentrations of WIOC, BC, and WSOC in different sample types for typical glaciers and monitor stations of the HTP.

\begin{tabular}{|c|c|c|c|c|c|c|c|c|c|c|c|c|}
\hline \multirow[t]{2}{*}{ Site } & \multirow[b]{2}{*}{ Sample type } & \multirow[b]{2}{*}{ Method } & \multirow[b]{2}{*}{ Reference } & \multirow[b]{2}{*}{ Acid treated } & \multicolumn{5}{|c|}{ Original reported data } & \multicolumn{3}{|c|}{ Adjusted data } \\
\hline & & & & & $\mathrm{WIOC}+\mathrm{BC}$ & WIOC & $\mathrm{BC}$ & WSOC & WIOC/BC & WIOC & $\mathrm{BC}$ & WIOC/BC \\
\hline Laohugou No.12 glacier & Snowpit & A & 1 & $\mathrm{Y}$ & 1.01 & 0.88 & 0.13 & 0.42 & 6.70 & 0.84 & 0.17 & 4.83 \\
\hline Xiaodongkemadi glacier & Snowpit & A & 1 & $\mathrm{Y}$ & 0.52 & 0.47 & 0.05 & 0.25 & 9.61 & 0.46 & 0.06 & 7.04 \\
\hline Xiaodongkemadi glacier & Fresh snow & $\mathrm{B}$ & 2 & $\mathrm{~N}$ & ND & 0.16 & 0.04 & ND & 3.78 & 0.12 & 0.03 & 4.84 \\
\hline Zhadang glacier & Snowpit & A & 1 & $\mathrm{Y}$ & 0.64 & 0.56 & 0.08 & 0.37 & 7.33 & 0.54 & 0.10 & 5.31 \\
\hline Zhadang glacier & Fresh snow & B & 3 & $\mathrm{~N}$ & ND & 0.82 & 0.30 & ND & 2.71 & 0.64 & 0.18 & 3.47 \\
\hline Yulong glacier & Snowpit & A & 1 & $\mathrm{Y}$ & 0.33 & 0.30 & 0.03 & 0.27 & 9.87 & 0.29 & 0.04 & 7.24 \\
\hline Demula glacier & Snowpit & A & 1 & $\mathrm{Y}$ & 0.23 & 0.21 & 0.02 & 0.19 & 11.57 & 0.21 & 0.02 & 8.52 \\
\hline Qiangyong glacier & Snowpit & A & 1 & $\mathrm{Y}$ & 0.326 & 0.30 & 0.03 & ND & 10.80 & 0.29 & 0.04 & 7.95 \\
\hline East Rongbu glacier & Snowpit & A & 1 & $\mathrm{Y}$ & 0.14 & 0.13 & 0.01 & 0.15 & 12.01 & 0.13 & 0.01 & 9.02 \\
\hline Thorung glacier & Snowpit & A & 1 & $\mathrm{Y}$ & 0.18 & 0.16 & 0.02 & ND & 7.85 & 0.15 & 0.03 & 5.70 \\
\hline Zuoqiupu glacier & Ice core & $\mathrm{B}$ & 4 & $\mathrm{Y}$ & 0.05 & 0.04 & 0.01 & ND & 4.79 & 0.04 & 0.01 & 4.79 \\
\hline Dongga glacier & Snowpit & B & 5 & $\mathrm{~N}$ & 0.38 & 0.28 & 0.10 & ND & 2.89 & 0.22 & 0.06 & 3.69 \\
\hline Renlongba glacier & Snowpit & B & 5 & $\mathrm{~N}$ & 1.14 & 0.82 & 0.32 & ND & 2.57 & 0.64 & 0.19 & 3.29 \\
\hline Demula glacier & Snowpit & B & 5 & $\mathrm{~N}$ & 0.30 & 0.18 & 0.13 & ND & 1.42 & 0.14 & 0.08 & 1.81 \\
\hline Tibet & Surface soil & $\mathrm{B}$ & 6 & $\mathrm{Y}$ & 20.99 & 18.97 & 2.02 & ND & 9.39 & 18.97 & 2.02 & 9.39 \\
\hline Nam Co station & $\mathrm{PM}_{2.5}$ & B & 7 & $\mathrm{Y}$ & 0.29 & 0.21 & 0.08 & 0.25 & 2.76 & 0.21 & 0.08 & 2.76 \\
\hline Lulang station & TSP & B & 8 & $\mathrm{~N}$ & 2.92 & 2.40 & 0.52 & 1.88 & 4.61 & 1.87 & 0.32 & 5.89 \\
\hline Everest station & TSP & B & 9 & $\mathrm{Y}$ & 0.91 & 0.66 & 0.25 & 0.77 & 2.64 & 0.51 & 0.15 & 3.38 \\
\hline Qinghai Lake & $\mathrm{PM}_{2.5}$ & B & 10 & $\mathrm{~N}$ & 2.75 & 1.91 & 0.84 & 1.55 & 2.27 & 1.49 & 0.51 & 2.91 \\
\hline Muztagh Ata & TSP & B & 11 & $\mathrm{Y}$ & 0.32 & 0.26 & 0.06 & 0.22 & 4.33 & 0.26 & 0.06 & 4.73 \\
\hline Baishui glacier & TSP & B & 12 & $\mathrm{~N}$ & 2.10 & 0.57 & 1.53 & 0.37 & 0.37 & 0.44 & 0.93 & 0.48 \\
\hline QSS station & $\mathrm{PM}_{2.5}$ & B & 13 & $\mathrm{~N}$ & 0.24 & 0.14 & 0.10 & 0.53 & 1.40 & 0.11 & 0.06 & 1.84 \\
\hline Nam Co station & Precipitation & B & 14 & $\mathrm{Y}$ & 0.21 & 0.19 & 0.02 & 1.05 & 10.38 & 0.19 & 0.02 & 10.38 \\
\hline Lulang station & Precipitation & B & 14 & $\mathrm{Y}$ & 0.36 & 0.33 & 0.03 & 0.83 & 9.53 & 0.33 & 0.03 & 9.53 \\
\hline Everest station & Precipitation & B & 14 & $\mathrm{Y}$ & 0.26 & 0.25 & 0.01 & 0.86 & 18.37 & 0.25 & 0.01 & 18.37 \\
\hline
\end{tabular}

Note: OC, BC and WSOC are organic carbon, black carbon, and water-soluble organic carbon, respectively. TOR and TOT are thermal-optical reflectance and thermaloptical transmittance, respectively. These estimates were derived by the IMPROVE-A TOR method. The units of water-insoluble organic carbon (WIOC) and BC in snow/precipitation samples are $\mathrm{mg} \mathrm{L}^{-1}$; units of WIOC and BC in surface soil and aerosol samples are $\mathrm{mg} \mathrm{g}^{-1}$ and $\mu \mathrm{g} \mathrm{m}^{-3}$, respectively. The OC/WSOC ratio for Lulang station was adapted from (Li et al., 2016d). The OC/WSOC ratio for the Muztagh Ata station was adapted from that of Qinghai Lake (Zhao et al., 2015). A and B represent NIOSH 5040 TOT and IMPROVE-A TOR, respectively. References indicated in this table are 1, (Li et al., 2016a; Li et al., 2016c); 2, (Li et al., 2017c); 3, (Li et al., 2018c); 4, (Xu et al., 2009); 5, (Zhang et al., 2017b); 6, (Gautam et al., 2019); 7, unpublished article; 8, (Zhao et al., 2013b); 9, (Cong et al., 2015); 10, (Zhao et al., 2015); 11, (Cao et al., 2009); 12, (Niu et al., 2018); 13, (Xu et al., 2015); and 14, (Yan et al., 2019). "Y" and "N" represent "yes" and "no", respectively; ND: no data.

the fringe of the HTP and low concentrations (e.g., $76 \mathrm{ng} \mathrm{m}^{-3}$ at Nam Co station) in the inner HTP because the former area is highly influenced by mineral dust and locally sourced anthropogenic emissions from nearby residential activities (Li et al., 2018b) (Fig. S1). Therefore, in contrast to Lulang and Everest, which experience high local emissions, the Nam Co station is characterized by low airborne aerosol concentrations (Yan et al., 2019). In particular, the Nam Co station is located in an open area with high vegetation coverage and few local residents; thus, local emissions are very low and easily diffuse into the atmosphere (Fig. S1C, Text. S3). Furthermore, the lowest aerosol optical depth value (0.05 at $500 \mathrm{~nm}$ ) in the HTP has been reported at Nam Co station (Cong et al., 2009) and is comparable to that in Antarctica (Six et al., 2005), thus indicating a highly clean atmosphere. Therefore, Nam Co station is an ideal site for studying the background atmospheric environment of the HTP.

\subsubsection{Carbonaceous particles in glacier snow/ice}

Several factors need to be noted during studies on carbonaceous matter in glacier snow/ice over the HTP. First, data from only snow pit and fresh snow samples in glacier regions retain the information of deposited particles. Second, because most glaciers in the HTP are valley glaciers, surface soil in the glacier regions is often transported by strong winds and deposited on the glacier surfaces (Fig. S3). Because surface soil particles may also contain OC and BC (Gautam et al., 2020; Li et al., 2019a), the contribution of carbonaceous particles directly deposited on glaciers from long-range atmospheric transport can be overestimated, especially in the ablation area where deposition of soil from nearby sources can be high. However, both long-range atmospheric deposition and locally transported fine silt particles from surface soil in the glacier regions reduce the albedo of the glaciers (Li et al., 2019b) (Fig. S3). Third, it is generally assumed that high altitude glaciers are located far from local sources, and that the dominant source of carbonaceous particles deposited on these glaciers are from long-range transport. However, this is not always the case. For instance, Mt. Nyainqêntanglha is located close to Lhasa, and one of its glaciers (Zhadang) has been shown to be influenced by Lhasa emissions (Fig. 1b) (Ming et al., 2013).

WSOC concentrations in snowpit samples of the HTP vary spatially, being higher $\left(0.42 \pm 0.29 \mathrm{mg} \mathrm{L}^{-1}\right)$ toward the north and lower toward the south $\left(0.15 \pm 0.06 \mathrm{mg} \mathrm{L}^{-1}\right)$, a trend also seen for BC (Li et al., 2016c). As particulate WIOC and $\mathrm{BC}$ are hydrophobic, they tend to be retained in the surface snow and ice during melting (Xu et al., 2012), so that WIOC and $\mathrm{BC}$ in aged snow and ice samples become enriched compared to their levels in fresh snow and snowpit samples. For instance, BC concentrations in fresh snow and aged ice samples obtained from the same glacier (i.e., Zhadang, middle HTP) were $41.77 \pm 6.36 \mu \mathrm{g} \mathrm{L}^{-1}$ and $634.27 \pm 104.42 \mu \mathrm{g} \mathrm{L}^{-1}$, respectively (Li et al., 2017c). It has also been found that BC is more likely to be removed by meltwater than mineral dust during the melting process, so the enrichment strength of mineral dust was higher than that of BC. Therefore, dust contributes more to glacier melt than BC after strong melt events (Hu et al., 2020). Studies of these processes for HTP glaciers are limited; thus, further studies covering more glaciers are required.

The WIOC/BC ratio differs during precipitation and snow melting processes. In general, the scavenging ratio of WIOC is higher than that of $\mathrm{BC}$ in the atmosphere, which has been found not only in the HTP (Yan et al., 2019), but also in other regions such as Europe (Cerqueira et al., 2010) and Japan (Huo et al., 2016). Therefore, for a given region, the WIOC/BC ratio in snow samples should be higher than the WIOC/BC ratio in atmospheric aerosols (Fig. S4a). In this study, the average WIOC/BC ratio $(3.59 \pm 1.47)$ in atmospheric aerosols obtained from 6 remote stations in the HTP (Text. S2) were utilized to compare with those of snowpit samples. The WIOC/BC ratios of snowpit samples 
reported in different studies in the HTP exhibit a large range, spanning 1.81 (Demula) (Zhang et al., 2017) to 9.02 (East Rongbu) (Li et al., 2016a; Li et al., 2016b) (Table 1). WIOC/BC ratios less than 3.59 contradict the above assertion that the scavenging ratio of WIOC is higher than that of BC. However, it can be explained by melt processes in snowpits, which result in enrichment of BC compared to WIOC and thus a low WIOC/BC ratio (Xu et al., 2012) (Fig. S4b). For instance, the WIOC/BC ratio of Demula snow samples collected in June 2015 was 1.81 (Zhang et al., 2017), lower than that in another study conducted at the same glacier at May 2014 of 8.52 (Li et al., 2016a) (Fig. S4, Table 1). The reason is that higher temperatures at the collecting time in the first study (Zhang et al., 2017) caused strong melting of snow and higher enrichment of BC than that of WIOC. Meanwhile, because the former study did not remove the influence of inorganic carbon (Zhang et al., 2017), the low reported WIOC/BC ratio was also likely caused by a higher contribution of inorganic carbon to BC than WIOC (Li et al., 2017a). Therefore, not all the data reported from HTP snowpits reflect direct atmospheric deposition, and need to be re-evaluated.

\subsubsection{Temporal variations in carbonaceous particles}

Seasonal variations in carbonaceous particle concentrations have been observed in different areas of the HTP. Specifically, atmospheric eBC concentrations in the southern HTP indicate seasonal variations that are primarily affected by the precipitation amount. For instance, low and high atmospheric eBC concentrations at the Everest station appear during summer and spring with heavy and light precipitation, respectively (Chen et al., 2018) (Fig. 2). In contrast, high atmospheric eBC concentrations occur during summer in the northern HTP (e.g., Qilian Shan Station (QSS station)) due to the dominant westerlies (Zhao et al.,

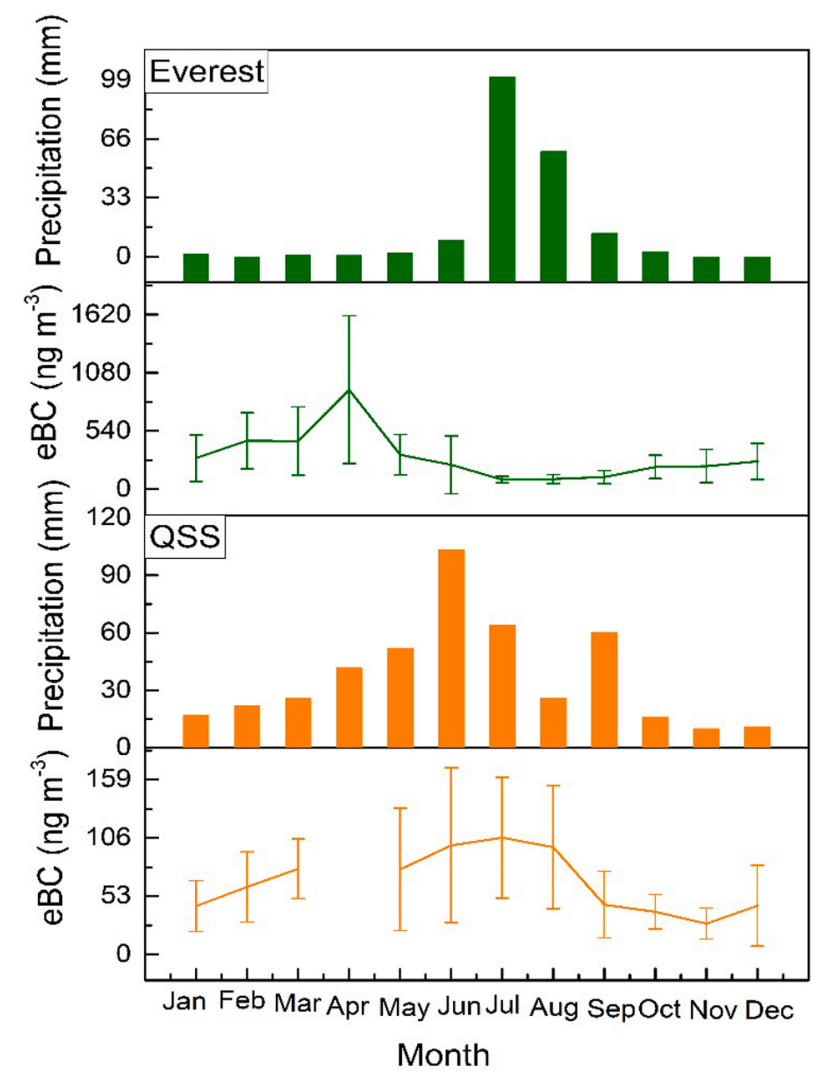

Fig. 2. Seasonal variation in atmospheric eBC concentrations and precipitation at two remote stations (Everest and Qilian Shan Station (QSS)) under the influence of the Indian monsoon and the westerlies, respectively. Data for Everest and QSS stations have been adapted from Zhao et al. (2012) and Chen et al. (2018), respectively. The data presented here do not consider the contribution of mineral dust because BC concentrations were measured by an aethalometer.
2012).

Diurnal variations in atmospheric eBC concentrations likely reflect variations in $\mathrm{eBC}$ sources and transport. To date, distinct diurnal variation characteristics in $\mathrm{eBC}$ have been reported at different remote stations, indicating a complex influence of factors such as micro-terrains, local sources, and advection. For instance, eBC concentrations at the southern HTP presented a peak during morning hours (6-8 am) (Chen et al., 2018; Wang et al., 2016; Zhang et al., 2017a; Zhao et al., 2017), suggesting contributions from local activities such as cooking and increased traffic. Meanwhile, the diurnal eBC variation at the Nam Co station is consistent with diurnal wind speed variation (Yin et al., 2017; Zhang et al., 2017a), indicating the influence of atmospheric advection. However, diurnal variations in eBC concentrations were not obvious at the western Muztagh Ata station (Zhu et al., 2016).

\subsection{Deposition of carbonaceous particles}

The deposition of carbonaceous particles is closely linked to their lifetime and transport. At present, most studies concerning the deposition of carbonaceous particles in the HTP are focused on BC (e.g., Bauer et al., 2013; Han et al., 2015; Ji et al., 2015; Yasunari et al., 2013; Zhang et al., 2015a), while related studies on OC are limited (Li et al., 2017b; Yan et al., 2019; Yan et al., 2020b).

Annual BC deposition rates based on snowpit samples from eight glaciers in the HTP were $17.9 \pm 5.3 \mathrm{mg} \mathrm{m}^{-2} \mathrm{a}^{-1}$ (Li et al., 2017a) (Fig. 3), which was far lower than that in highly polluted East China (1160 $\mathrm{mg} \mathrm{m}^{-2} \mathrm{a}^{-1}$ ) (Han et al., 2016). This is because atmospheric BC concentrations in the high glaciers mainly reflect the background $\mathrm{BC}$ level in the middle and upper troposphere (under certain meteorological conditions). Additionally, other local factors have been shown to exert little influence. Compared to BC deposition in high-altitude glacier regions (Li et al., 2017a), corresponding data at the stations located at low altitude indicate large variability due to complex contributions from locally sourced emissions and mineral dust in addition to deposition from long - range sources (Yan et al., 2019). A detailed study on carbonaceous matter deposition directly from the atmosphere at three remote stations (Nam Co, Lulang, and Everest) of the HTP has shown that the total BC deposition at Nam Co, Lulang, and Everest stations were 15.3, 58.9, and $9.7 \mathrm{mg} \mathrm{m}^{-2} \mathrm{a}^{-1}$, respectively. These results were consistent with the spatial patterns of wet deposition of WSOC at these stations (Li et al., 2017b).

An interesting phenomenon in the HTP is the high contribution of

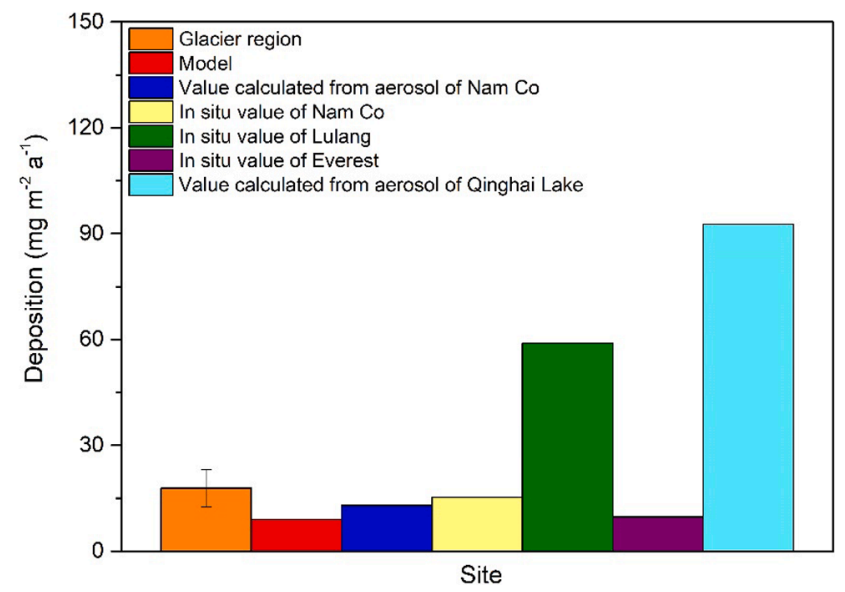

Fig. 3. Atmospheric BC deposition rates in the HTP derived from glaciers, models, BC concentrations in aerosol samples (Li et al., 2017a), and direct dry/ wet deposition measurements (Yan et al., 2019). Note: Deposition in the glacier region $\left(17.9 \pm 5.3 \mathrm{mg} \mathrm{m}^{-2} \mathrm{a}^{-1}\right)$ is considered representative of the HTP. Lower or higher values could be attributed to local factors such as low precipitation amounts (Everest station) and local emissions (Lulang station). 
dry deposition. Dry deposition accounted for approximately $62 \%, 41 \%$, and $73 \%$ of the total BC deposition at Nam Co, Lulang, and Everest stations, respectively. These values are high considering that wet deposition generally accounts for a larger fraction of the total BC deposition (Jurado et al., 2008). It is likely that relatively high atmospheric mineral dust concentrations in the HTP and limited precipitation contributed to the large dry deposition of BC. For instance, the ratio of mineral dust concentration to carbonaceous particle concentration in TSP sampled from the Nam Co station is approximately 9.0 (Li et al., 2017a). Generally, the dry deposition velocity increased rapidly with increasing particle size (Zhang et al., 2001). Mean mineral dust particles of the HTP are larger than $11 \mu \mathrm{m}$ (Dong et al., 2016), larger than those of carbonaceous particles of less than $2.5 \mu \mathrm{m}$, thus resulting in higher dry deposition rates. The $\mathrm{OC}$ and $\mathrm{BC}$ concentrations in fine particles from surface soil $(<20 \mu \mathrm{m})$ in the HTP are $18.97 \pm 16.03$ and $2.02 \pm 1.55 \mathrm{mg}$ $\mathrm{g}^{-1}$, respectively (Gautam et al., 2019), suggesting that the dry deposition of $\mathrm{OC}$ and BC in fine particles from surface soil significantly contributes to the dry deposition of carbonaceous matter. In addition, in situ measured ratios of $\mathrm{BC}$ dry and wet deposition are higher than those simulated by typical climate models (Yan et al., 2019). Therefore, current models need to incorporate the contribution of dry deposition of fine particles from surface soil containing carbonaceous matter, especially in the western and northern regions of the HTP, which are characterized by dry environments and heavy dust storms (Fig. 1).

Furthermore, the total deposition of WIOC and BC at the Everest and Lulang stations are significantly higher than deposition on nearby glaciers. This could be attributed to locally sourced coarse particles (primarily comprising OC) (Yan et al., 2019), which are difficult to transport to high-altitude glaciers. Sparser vegetation coverage around the stations is associated with higher measured atmospheric particle concentrations (Liu et al., 2017). Therefore, the total in situ WIOC and BC deposition at these stations are probably overestimated due to the contribution of the local fine particles from the surface soil of the HTP itself.

Seasonally, the wet deposition rates of WIOC and BC are influenced by their atmospheric concentrations and precipitation, with precipitation exerting a more significant effect (Fig. 4). The wet deposition ratios of WIOC, WSOC and BC at the three sites varied with precipitation amount, with high and low values in the monsoon and nonmonsoon periods, respectively. Generally, concentrations of carbonaceous matter in precipitation indicate a significant negative correlation with precipitation amounts, especially in polluted areas with high aerosol concentrations, which depend on whether they are dominated by the scavenging or dilution effect (Rastogi and Sarin, 2005; Yan and Kim, 2012). Here, BC and WIOC concentrations in precipitation indicated a nonsignificant correlation with precipitation amounts at the three studied remote stations. It has been suggested that washout and rainout processes are both incorporated in precipitation events (Ishikawa et al., 1995). At present, although it is difficult to determine the dominant mechanism in the scavenging process at the three study stations of the HTP, the low particle concentrations in the atmosphere of Nam Co, Lulang and Everest stations should be the main factor causing the low correlation. The $\mathrm{BC}$ scavenging ratio is defined as the ratio of the $\mathrm{BC}$ concentration in the precipitation to the $\mathrm{BC}$ concentration in the atmosphere (Ducret and Cachier, 1992). The BC scavenging ratio at Nam Co station was $0.24 \times 10^{6}$ (Yan et al., 2019), consistent with those in remote regions (e.g., Schauinsland, Germany) (Cerqueira et al., 2010), thus suggesting that this station could potentially represent remote sites in the inner HTP. BC scavenging ratios at Lulang and Everest stations were lower than those at Nam Co station because of the contribution of local emissions with hydrophobic particles (e.g., those from local residential burning, vehicles, and mineral dust) (Yan et al., 2019).

\subsection{Sources of carbonaceous matter}

\subsubsection{Biomass and fossil fuel combustion}

Combustion emissions and condensed semi-volatile organic compounds are the main sources of carbonaceous particles (Pio et al., 2007; Qi and Wang, 2019; Szidat et al., 2004; Winiger et al., 2019). BC is mainly generated from biomass and fossil fuel combustion (e.g., Gustafsson et al., 2009; Szidat et al., 2004). However, sources of OC are complex and include combustion activities, fine particles from surface
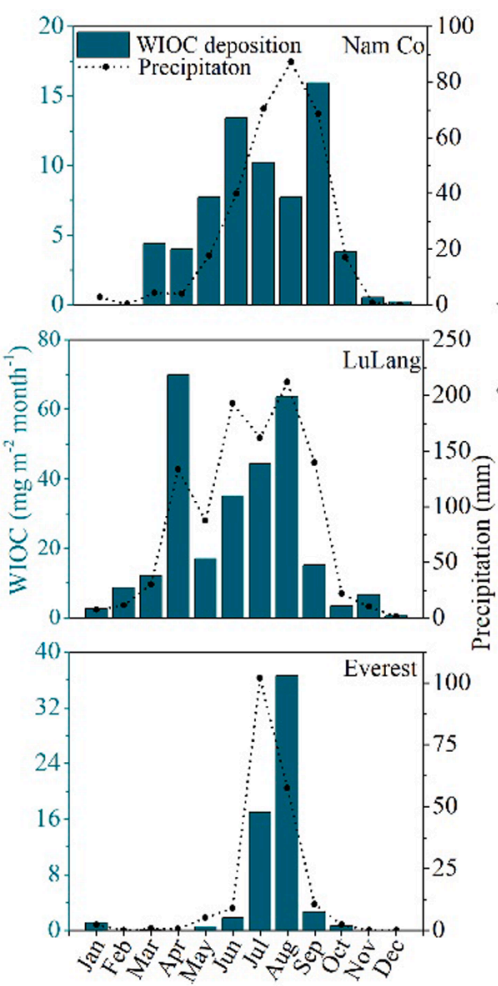
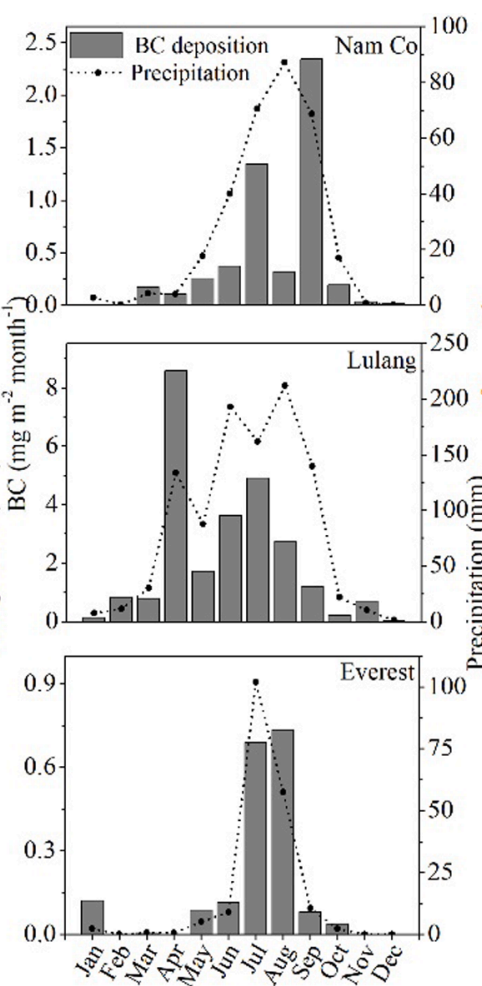
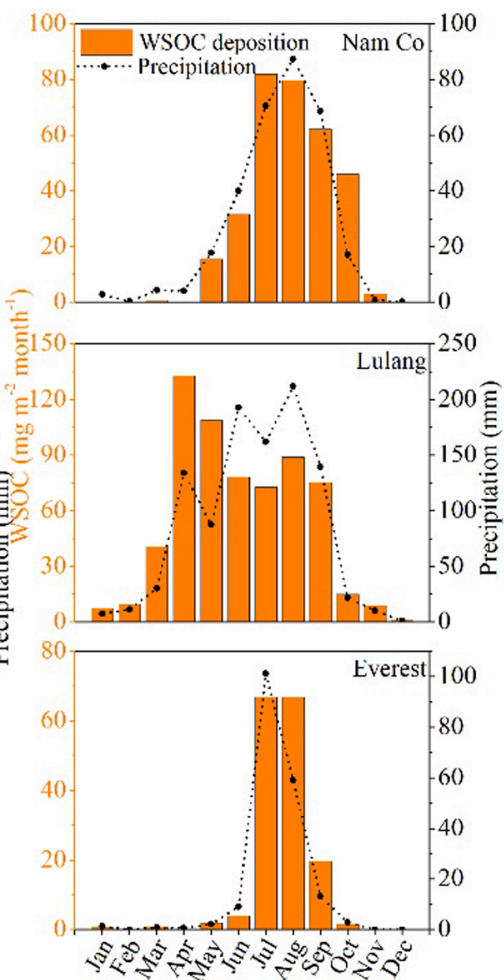

Fig. 4. Seasonal wet deposition rates of WIOC, BC (Yan et al., 2019), and WSOC (Li et al., 2017b) at Nam Co, Lulang, and Everest stations. 
soil, pollen, and secondary organic processes. Therefore, it is more straightforward to investigate the sources of BC than those of OC. Furthermore, the contribution of fossil and non-fossil fuel sources to WSOC in precipitation can be distinguished by the radiocarbon method (especially if the contribution of fine particles from surface soil is low) (Raymond, 2005; Stubbins et al., 2012). In general, the contribution of fossil fuel burning to $\mathrm{BC}$ and WSOC in precipitation decreases from the outer to the inner regions of the HTP (Li et al., 2016a; Li et al., 2018a) (Fig. 5).

Some valleys that cut across the Himalayas have been proposed as important conduits for pollution transport from highly polluted South Asia to the Tibetan Plateau (Dhungel et al., 2018; Zhang et al., 2020). It has been reported that $\mathrm{BC}$ atmospheric concentrations and the associated contribution from fossil fuel combustion decrease from South Asia to the inner HTP (Fig. 5) (Li et al., 2016a) for two reasons. First, pollutants from South Asia are diluted and deposited across the valleys
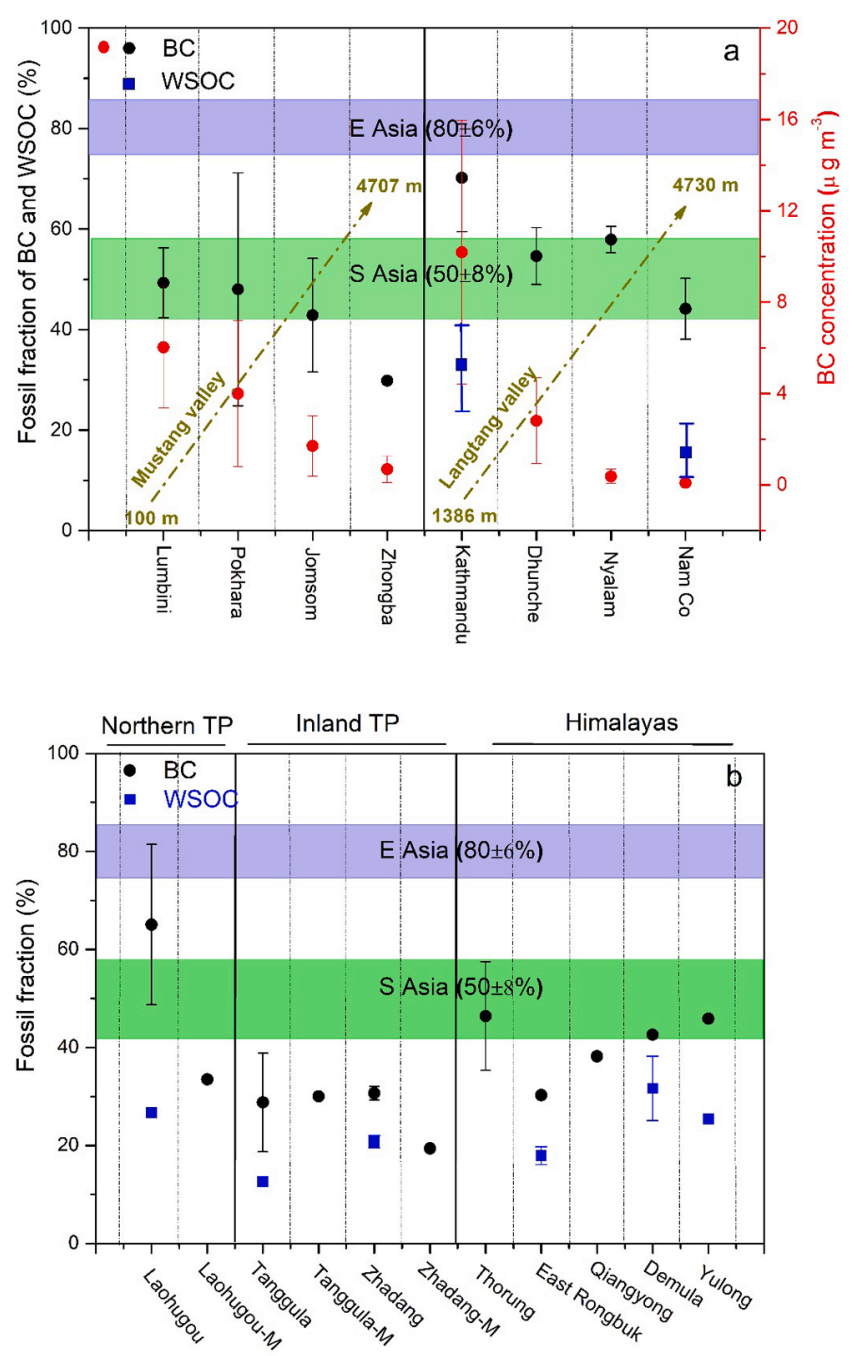

Fig. 5. Contributions of fossil fuel burning to BC (in aerosol, snowpit, and precipitation samples) and WSOC (in snowpit and precipitation samples) in the HTP. (a) Aerosol samples were collected from two valleys across the Himalayas (black dots), and precipitation samples (for WSOC) were obtained from Nam Co and Kathmandu (blue squares). (b) Snowpit samples were obtained from the HTP. Data for BC in aerosol and snowpit samples were adapted from (Li et al., 2016a). Data for WSOC in precipitation and snowpit samples were adapted from (Li et al., 2018a). Purple and green belts represent fossil contributions of East Asia and South Asia, respectively. "-M" represents monsoon period; TP represents the Tibetan Plateau. (For interpretation of the references to color in this figure legend, the reader is referred to the web version of this article.) during transport (Fig. S5). Second, local non-fossil fuel sources of BC (e. g., biomass combustion) significantly contribute to atmospheric pollution in the Himalayan region. Although particles from biomass combustion can be transported over long distances (Forster et al., 2001), their strong hydrophilicity makes the long-distance transport efficiency lower than that of particles from fossil fuel combustion (Pio et al., 2007).

Similarly, the contribution of BC from fossil fuel combustion in snowpits decreases from the outer to inner regions of the HTP (Fig. 5b). Glaciers in the inner HTP are primarily influenced by local biomass combustion (Hu et al., 2018a) because local residents of the Tibetan Plateau burn yak dung and biomass for cooking and heating (Chen et al., 2015; Xiao et al., 2015). In contrast, the fraction of BC driven by fossil fuel combustion in urban cities of the HTP (i.e., Lhasa) is high (Li et al., 2016a) and similar to those in megacities of East China such as Beijing (Chen et al., 2013).

Generally, OC of a given sample (e.g., aerosol or snowpit sample) is younger and more enriched in $\triangle^{14} \mathrm{C}$ than that of $\mathrm{BC}$, which has been shown in previous studies conducted in a number of regions in the world such as Europe (Szidat et al., 2004), South Asia (Gustafsson et al., 2009) and East China (Zhang et al., 2015b). The fossil fuel contribution to WSOC in precipitation at the Nam Co station has been reported as $15 \pm$ $6 \%$, which is lower than that observed for typical urban cities in South Asia (Kathmandu, $33 \pm 9 \%$ ) and East Asia (Kunming, $36 \pm 10 \%$ ) (Li et al., 2018a) (Fig. 5).

Similar results have also been observed for snowpit samples, suggesting the presence of $\mathrm{OC}$ from biomass/biogenic sources in precipitation samples. Previous research has concluded that precipitation events are driven by Indian airmasses at Nam Co station that generally show higher fossil fuel contributions than by airmasses from the Westerlies (Li et al., 2018a), suggesting long-distance transport of pollutants from South Asia. However, Lhasa is approximately $100 \mathrm{~km}$ to the south of Nam Co station. Therefore, distinguishing fossil fuel-sourced emissions from Lhasa and long-range transported pollutants from South Asia is challenging. The $\delta^{13} \mathrm{C}$ of WSOC is expressed as the measured ratio of stable isotopes ${ }^{13} \mathrm{C} /{ }^{12} \mathrm{C}$ relative to that of the Pee Dee Belemnite (PDB) standard by the equation $\delta^{13} \mathrm{C}=\left[\left({ }^{13} \mathrm{C} /{ }^{12} \mathrm{C}\right)_{\text {sample }} /\left({ }^{13} \mathrm{C} /{ }^{12} \mathrm{C}\right)_{\text {standard }}-1\right] \times$ $10^{3}$ (Narukawa et al., 1999). Both aging processes and photochemical reactions (Mladenov et al., 2011) can alter the original source $\delta^{13} \mathrm{C}$ signature of WSOC. $\delta^{13} \mathrm{C}$ at Nam Co in precipitation samples after the potential influence of inorganic carbon in mineral dust was removed by acid has been reported as $-21 \pm 3 \%$ ( $L i$ et al., 2018a). This value was similar to that of snowpit samples $(-21 \pm 3 \%$ o) but enriched compared to those of OC in surface soil samples from the HTP $(-25.4 \pm 0.6 \%$ ) and precipitation WSOC in urban cities (i.e., Lhasa: $-25 \pm 2 \%$ ) (Fig. S6), thus indicating the occurrence of nontrivial OC aging processes (Narukawa et al., 1999) and photochemical reactions (Miller and Zepp, 1995; Mladenov et al., 2011) during transport to the Nam Co station and the glaciers. Therefore, precipitation WSOC at the Nam Co station likely experienced long-distance transport.

\subsubsection{Sources supplying carbonaceous particles to subregions of the HTP}

It is complex and challenging to determine the regional sources of carbonaceous particles in the HTP due to: (1) the large area of the region, (2) different sub-regions of the HTP have different sources of carbonaceous particles, and (3) the network of observations and monitoring stations are sparsely distributed. Commonly used methods such as backward air mass trajectory analysis (Li et al., 2016d; Zhao et al., 2013b) and the use of fire points (Chen et al., 2018) or emission inventories (Zhang et al., 2017b) can be used to constrain subregion carbonaceous particle sources, but these methods only indirectly imply the potential sources of BC within the HTP.

Based on the $\delta^{18} \mathrm{O}$ in the precipitation, the HTP can be divided into three subareas (i.e., northern and western region, middle region and southern region) (Yao et al., 2013), similar to the distributions of $\triangle{ }^{14} \mathrm{C}$ from BC in snowpit samples. Meanwhile, an increasing body of evidence suggests significant contributions of local sources to BC concentrations 
at specific sites (Li et al., 2018b; Yan et al., 2019). Therefore, although long-distance transported $\mathrm{BC}$ significantly affects most regions of the HTP, the contribution of locally sourced BC is significant not only in cities and towns but also at some remote stations in narrow valleys or close to busy roads and emission sources. OC sources can be indirectly determined from BC sources. Because OC adheres more easily than BC on larger particles such as mineral dust, OC has less potential for longdistance transport than BC. However, fine OC still plays an important role in the aerosol compositions at remote HTP sites. For instance, the annual fine OC accounted for approximately $61 \%$ of the mass concentration of TSP at Nam Co station during 2012 (Wan et al., 2015).

\subsection{Light absorption characteristics of carbonaceous matter}

The light absorption ability of carbonaceous matter is assessed by MAC values, which provide fundamental input data for studies on the radiative forcing of aerosols (Petzold et al., 2013). The referenced $\mathrm{MAC}_{\mathrm{BC}}$ value for freshly emitted particles is approximately $7.5 \pm 1.2 \mathrm{~m}^{2}$ $\mathrm{g}^{-1}$ at $550 \mathrm{~nm}$ (Bond and Bergstrom, 2006). Although the light absorption by $\mathrm{OC}$ is limited at this wavelength, it increases significantly at shorter wavelengths (Schnaiter et al., 2006). In general, $\mathrm{MAC}_{\mathrm{OC}}$ is derived at $365 \mathrm{~nm}$ (Cheng et al., 2017; Kirillova et al., 2014). Both $\mathrm{MAC}_{\mathrm{BC}}$ and $\mathrm{MAC}_{\mathrm{OC}}$ values vary with particle source, particle size distribution, structures/morphology and atmospheric processes that particles experience (e.g., coating and bleaching) (Chen et al., 2017; Martinsson et al., 2015). For example, $\mathrm{MAC}_{\mathrm{BC}}$ at $550 \mathrm{~nm}$ usually peaks around a particle diameter of $150 \mathrm{~nm}$ and starts to decrease as the particle diameter increases from $150 \mathrm{~nm}$ to larger values (Bond et al., 2006). Moreover, the particle morphology for both fresh and coated BC also significantly affects $\mathrm{MAC}_{\mathrm{BC}}$, with up to a factor of 2 variation in $\mathrm{BC}$ absorption due to different coating morphologies and generally larger MAC values for fully coated BC particles than for partially coated particles (Bond et al., 2013; He et al., 2015; He et al., 2016). Therefore, $\mathrm{MAC}_{\mathrm{BC}}$ and $\mathrm{MAC}_{\mathrm{OC}}$ indicate large spatiotemporal variations (Forrister et al., 2015; Gustafsson and Ramanathan, 2016). As a result, in situ MAC values of carbonaceous matter in the HTP are important in accurately evaluating $\mathrm{OC}$ and $\mathrm{BC}$ radiative forcing.

The $\mathrm{MAC}_{\mathrm{BC}}$ can be calculated from measured data (Text S1.5) (Petzold et al., 2013). Although the $\mathrm{MAC}_{\mathrm{BC}}$ based on the thermal-optical method can be influenced by many factors (e.g., decreases in incident light with increased filter loading and aerosol scattering effects) (Andreae and Gelencser, 2006; Bond and Bergstrom, 2006; Kondo et al., 2009), this method provides MAC values that are used in radiative forcing calculations (Cheng et al., 2011; Ram and Sarin, 2009).

The average $\mathrm{MAC}_{\mathrm{BC}}$ values at $632 \mathrm{~nm}$ for Lulang and Everest stations were $6.85 \pm 1.39$ and $6.49 \pm 2.81 \mathrm{~m}^{2} \mathrm{~g}^{-1}$, respectively. These values are comparable to values for freshly emitted BC $\left(6.5 \pm 1.0 \mathrm{~m}^{2} \mathrm{~g}^{-1}\right)$ (Table 2) (Bond and Bergstrom, 2006). These results indicate that the BC at these two stations likely originated from primary local sources with weak aging/coating influences. Previous studies on the HTP have indicated that $\mathrm{MAC}_{\mathrm{BC}}$ values of fossil fuel-sourced $\mathrm{BC}$ at $632 \mathrm{~nm}$ are approximately $25 \%$ higher than those of biomass combustion-sourced BC (Hu et al., 2017). Accordingly, $\mathrm{MAC}_{\mathrm{BC}}$ values at Lulang and Everest stations were lower than those reported for Lhasa and Beijing of $7.19 \pm 1.19 \mathrm{~m}^{2} \mathrm{~g}^{-1}$ and $9.41 \pm 1.92 \mathrm{~m}^{2} \mathrm{~g}^{-1}$, respectively (Cheng et al., 2011; Li et al., 2016b). Notably, the $\mathrm{MAC}_{\mathrm{BC}}$ value for the Nam Co station has been reported as $12.2 \pm 3.4 \mathrm{~m}^{2} \mathrm{~g}^{-1}$ (Table. 2 ), which is significantly higher than those of freshly emitted particles (Cheng et al., 2017). It has been suggested that some models underestimate the radiative forcing of $\mathrm{BC}$ primarily due to inappropriate treatments of the mixing of $\mathrm{BC}$ with other constituents (Bond et al., 2013). Therefore, $\mathrm{MAC}_{\mathrm{BC}}$ values for Nam Co aerosols can be adapted in future models.

The MAC ${ }_{W S O C}$ values at $365 \mathrm{~nm}$ for TSP samples collected from Nam Co, Lulang, and Everest stations were $1.74 \pm 0.94\left(1.22 \pm 0.44 \mathrm{~m}^{2} \mathrm{~g}^{-1}\right.$ for $\mathrm{PM}_{2.5}$ samples), $0.84 \pm 0.40$, and $1.18 \pm 0.64 \mathrm{~m}^{2} \mathrm{~g}^{-1}$, respectively (Li et al., 2016d). These values were comparable to those in urban cities of
Table 2

$\mathrm{MAC}_{\mathrm{WSOC}}, \mathrm{MAC}_{\mathrm{BC}}$, and $\mathrm{AAE}_{\mathrm{WsOC}}$ values from aerosol particles, surface soils in the HTP and previous studies.

\begin{tabular}{|c|c|c|c|c|c|}
\hline \multirow{2}{*}{$\begin{array}{l}\text { Site/ } \\
\text { sample } \\
\text { type } \\
\text { Nam Co }\end{array}$} & \multirow{2}{*}{$\begin{array}{l}\text { Particle } \\
\mathrm{PM}_{2.5}\end{array}$} & \multirow{2}{*}{$\begin{array}{l}\text { MAC WSOC }_{\text {}} \\
1.22 \pm \\
0.43\end{array}$} & \multirow{2}{*}{$\begin{array}{l}\mathrm{AAE}_{330-} \\
400 \\
4.13 \pm \\
1.38\end{array}$} & \multicolumn{2}{|c|}{$\mathrm{MAC}_{\mathrm{BC}}$ Reference } \\
\hline & & & & $\begin{array}{l}12.2 \\
\pm 3.36\end{array}$ & A \\
\hline Nam Co & $\mathrm{PM}_{2.5}$ & $\begin{array}{l}0.38 \pm \\
0.16\end{array}$ & $\begin{array}{l}6.19 \pm \\
1.70\end{array}$ & ND & $\begin{array}{l}\text { (Zhang et al., } \\
\text { 2017c) }\end{array}$ \\
\hline $\begin{array}{l}\text { Surface } \\
\text { soil }\end{array}$ & & $\begin{array}{l}1.67 \pm \\
0.38\end{array}$ & $\begin{array}{l}4.53 \pm \\
0.88\end{array}$ & ND & (Li et al., 2017b) \\
\hline Everest & TSP & $\begin{array}{l}1.18 \pm \\
0.64\end{array}$ & $\begin{array}{l}4.64 \pm \\
1.15\end{array}$ & $\begin{array}{l}6.49 \\
\pm 2.81\end{array}$ & (Li et al., 2016b) \\
\hline Lulang & TSP & $\begin{array}{l}0.84 \pm \\
0.40\end{array}$ & $\begin{array}{l}5.39 \pm \\
1.22\end{array}$ & $\begin{array}{l}6.85 \\
\pm 1.39\end{array}$ & (Li et al., 2016b) \\
\hline Lulang & & ND & ND & 7.6 & $\begin{array}{l}\text { (Wang et al., } \\
\text { 2018) }\end{array}$ \\
\hline Ngari & TSP & ND & ND & $\begin{array}{l}14.3 \\
\pm 6.54\end{array}$ & $\begin{array}{l}\text { (Chen et al., } \\
\text { 2019) }\end{array}$ \\
\hline Lhasa & $\mathrm{PM}_{2.5}$ & $\begin{array}{l}0.74 \pm \\
0.22\end{array}$ & 5.38 & $\begin{array}{l}7.19 \\
\pm 1.19\end{array}$ & (Li et al., 2016d) \\
\hline $\begin{array}{l}\text { Los } \\
\quad \text { Angeles }\end{array}$ & $\mathrm{PM}_{2.5}$ & 0.71 & ND & ND & $\begin{array}{l}\text { (Zhang et al., } \\
\text { 2013) }\end{array}$ \\
\hline $\begin{array}{l}\text { Beijing, } \\
\text { summer }\end{array}$ & $\mathrm{PM}_{2.5}$ & $\begin{array}{l}0.44 \pm \\
0.06\end{array}$ & $\begin{array}{l}7.18 \pm \\
0.31\end{array}$ & $\begin{array}{l}9.41 \\
\pm 1.92\end{array}$ & $\begin{array}{l}\text { (Cheng et al., } \\
\text { 2017) }\end{array}$ \\
\hline $\begin{array}{l}\text { Beijing, } \\
\text { winter }\end{array}$ & $\mathrm{PM}_{2.5}$ & $\begin{array}{l}1.54 \pm \\
0.16\end{array}$ & ND & ND & (Yan et al., 2015) \\
\hline Seoul & $\mathrm{PM}_{2.5}$ & $0.28-1.18$ & $\begin{array}{l}7.23 \pm \\
1.58\end{array}$ & ND & (Kim et al., 2016) \\
\hline NCO-P & $\mathrm{PM}_{10}$ & $\begin{array}{l}0.57 \pm \\
0.18\end{array}$ & $4.9 \pm 0.7$ & ND & $\begin{array}{l}\text { (Kirillova et al., } \\
\text { 2016) }\end{array}$ \\
\hline $\begin{array}{l}\text { New Delhi } \\
\text { (IGP) }\end{array}$ & $\mathrm{PM}_{10}$ & $1.6 \pm 0.5$ & $5.1 \pm 2.0$ & ND & $\begin{array}{l}\text { (Kirillova et al., } \\
\text { 2014) }\end{array}$ \\
\hline $\begin{array}{l}\text { Patiala } \\
\text { (IGP) }\end{array}$ & $\begin{array}{l}\mathrm{PM}_{2.5} \\
\text { (day) }\end{array}$ & $1.3 \pm 0.7$ & $5.1 \pm 1.9$ & $\begin{array}{l}4.2 \pm \\
1.4\end{array}$ & $\begin{array}{l}\text { (Srinivas et al., } \\
\text { 2016) }\end{array}$ \\
\hline $\begin{array}{l}\text { Bay of } \\
\text { Bengal }\end{array}$ & TSP & $0.4 \pm 0.1$ & $9.1 \pm 3.6$ & ND & $\begin{array}{l}\text { (Srinivas and } \\
\text { Sarin, 2013) }\end{array}$ \\
\hline $\begin{array}{l}\text { Source } \\
\text { samples }\end{array}$ & & & & & \\
\hline Wood & $\mathrm{PM}_{2.5}$ & $0.13-1.1$ & $8.6-17.8$ & ND & $\begin{array}{l}\text { (Chen and Bond, } \\
\text { 2010; Hu et al., } \\
\text { 2017) }\end{array}$ \\
\hline $\begin{array}{l}\text { Vehicle } \\
\text { emission }\end{array}$ & $\mathrm{PM}_{2.5}$ & $\begin{array}{l}0.71 \pm \\
0.17\end{array}$ & $\begin{array}{l}4.06 \pm \\
1.11\end{array}$ & $\begin{array}{l}6.06 \\
\pm 1.08\end{array}$ & $\begin{array}{l}\text { (Chen and Bond, } \\
\text { 2010; Hu et al., } \\
\text { 2017) }\end{array}$ \\
\hline
\end{tabular}

Note: A, unpublished article; AAE: absorption Ångström exponent; NCO-P: Nepal Climate Observatory-Pyramid; IGP: Indo-Gangetic Plain. ND: no data.

South Asia (Kirillova et al., 2014; Srinivas et al., 2016) but higher than those in the remote Indian Ocean (Bosch et al., 2014; Srinivas and Sarin, 2013) (Table 2), indicating a decreasing trend for aerosol MAC $\mathrm{WSOC}_{\mathrm{W}}$ values from continent to ocean. The higher values at the Nam Co and Everest stations than at the Lulang station indicate a significant contribution of WSOC in fine particles from surface soil (which indicates a higher MAC value there than in particles from fossil and biomass combustion) (Hu et al., 2018b) (Table 2). Furthermore, the MAC Wsoc values at Nam Co, Lulang, and Everest stations indicated similar seasonal variation, with high and low values occurring during non-monsoon and monsoon periods, respectively. This could be attributed to the reduction in fine particles from surface soil concentrations in the atmosphere during the monsoon period (Fig. 6). These results suggest that locally sourced fine particles from surface soil significantly contribute to spatiotemporal variations in the MAC Wsoc values over the HTP. Therefore, it is assumed that fine particles from surface soil exert a more significant effect on $\mathrm{MAC}_{\mathrm{WSOC}}$ values in the northern and western HTP, where frequent dust storms are experienced. Meanwhile, other factors, such as increased fossil fuel combustion (Du et al., 2014) and photobleaching of light absorption components of WSOC during this period (Li et al., 2016d), can also result in reduced MAC Wsoc.

It has been estimated that the amount of solar energy absorbed by WSOC is $16 \pm 10 \%, 6 \pm 4 \%$, and $11 \pm 7 \%$ of the amount of solar energy 


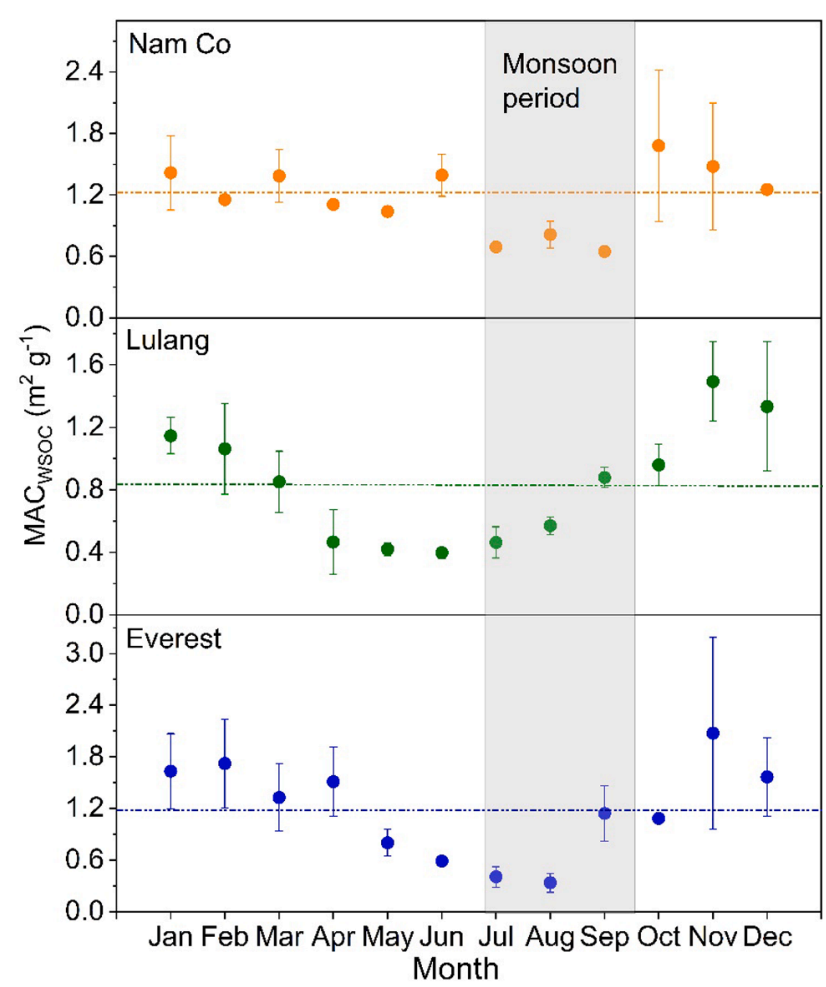

Fig. 6. Seasonal variation in $\mathrm{MAC}_{\mathrm{WsOC}}$ at $365 \mathrm{~nm}$ for Nam Co, Lulang, and Everest stations (Li et al., 2016d). Note: Data for Nam Co station were obtained from $\mathrm{PM}_{2.5}$ samples collected from December 2016 to December 2017 (unpublished data).

absorbed by BC at the Nam Co, Lulang, and Everest stations, respectively. Seasonally, absorption by WSOC and the WSOC/EC absorption ratio are highest during winter and lowest during summer (Li et al., 2016d). These results highlight the contribution of WSOC to total light absorption by carbonaceous particles of the HTP. At present, because few data on the light absorption of WIOC are available for the HTP and the existing data have large uncertainties (Yan et al., 2020a), MAC ${ }_{W I O C}$ is not included in the calculation of radiative forcing. Therefore, the actual relative importance of $O C$ in the total radiative forcing of carbonaceous particles should be higher than that of the aforementioned values.

The average $\mathrm{MAC}_{\mathrm{WSOC}}$ values for precipitation samples from the Nam Co, Lulang, Everest, and Yulong stations have been reported as $0.48 \pm 0.47 \mathrm{~m}^{2} \mathrm{~g}^{-1}, 0.25 \pm 0.15 \mathrm{~m}^{2} \mathrm{~g}^{-1}, 0.64 \pm 0.49 \mathrm{~m}^{2} \mathrm{~g}^{-1}$, and $0.43 \pm$ $0.32 \mathrm{~m}^{2} \mathrm{~g}^{-1}$, respectively (Li et al., 2017b; Niu et al., 2019). These values are significantly lower than those reported for aerosols $(\mathrm{p}<0.01)$ (Fig. 7), which could be attributed to high concentrations of secondary organic aerosols and biogenic VOCs with low light absorption in precipitation (Hallquist et al., 2009; Lambe et al., 2013). Similar results have been observed in severely polluted regions (e.g., Lhasa and East China) (Cheng et al., 2011; Li et al., 2017b; Yan et al., 2015), thus indicating that this general phenomenon occurs in both remote sites and urban cities. Due to the remoteness and lack of infrastructure in the HTP, the collection of aerosol samples in the high-altitude glacier regions there is rare. However, $\mathrm{MAC}_{\mathrm{WSOC}}$ for samples collected from snowpits can provide surrogate information. For instance, the $\mathrm{MAC}_{\mathrm{WSOC}}$ in fresh snow at a glacier of the northern HTP was $0.38 \pm 0.06 \mathrm{~m}^{2} \mathrm{~g}^{-1}$ (Hu et al., $2018 b$ ), which was close to the values for precipitation samples at remote stations. Thus, it is proposed that the $\mathrm{MAC}_{\mathrm{WSOC}}$ values of aerosols in the atmosphere over this glacier should be comparable to those of remote stations.

The concentration and light absorption ability of WSOC can vary substantially. For instance, the concentrations and light-absorbing

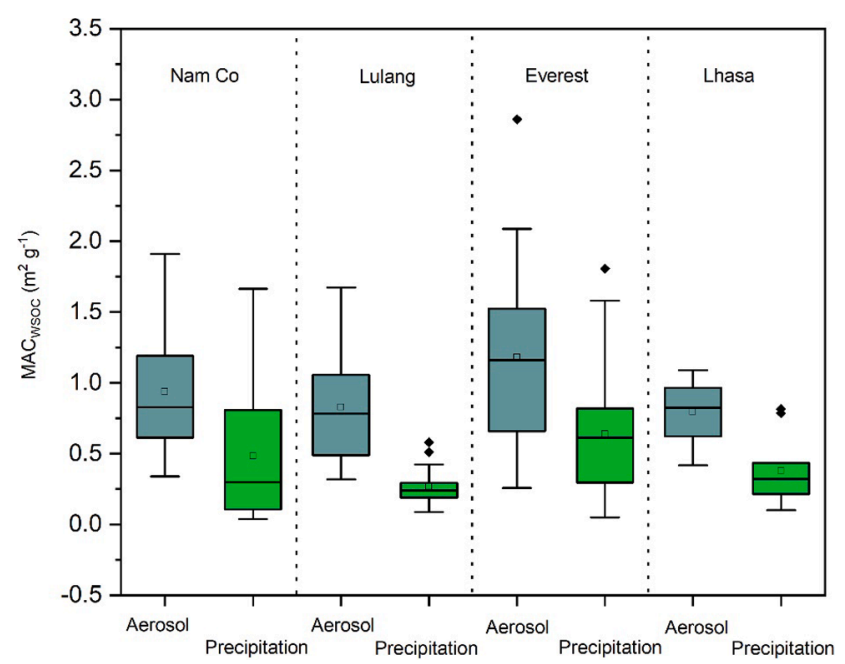

Fig. 7. $\mathrm{MAC}_{\mathrm{WSOC}}$ values for aerosol and precipitation samples from the Nam Co, Lulang, and Everest stations and Lhasa. Data for the Nam Co, Lulang, and Everest stations were adapted from (Li et al., 2017b); data on aerosol $\left(\mathrm{PM}_{10}\right)$ and precipitation samples from Lhasa were adapted from (Li et al., 2016b) and (Li et al., 2017b), respectively.

properties of WSOC in snow and ice samples vary greatly during melting. This phenomenon is also referred to as "fractionation of WSOC" (Hu et al., 2018b). Fractions of hydrophobic WSOC characterized by high light absorption attach to particles (e.g., mineral dust) during melting (Meyer et al., 2008). This mechanism also explains the lower $\mathrm{MAC}_{\mathrm{WSOC}}$ values in precipitation than in aerosols. A study on Laohugou glacier No. 12 concluded that WSOC concentrations and MAC ${ }_{W S O C}$ in surface ice indicated decreasing and increasing trends, respectively, as the melting strength increased from the upper to the lower part of the glaciers (Hu et al., 2018b). These results indicate the occurrence of the fractionation process, which was further corroborated by a controlledstep freezing experiment with WSOC in surface ice and topsoil samples (Hu et al., 2018b). The results of this experiment showed that the WSOC concentrations of treated samples increased rapidly from the earliest frozen samples to the last frozen samples. In contrast, $\mathrm{MAC}_{\mathrm{WSOC}}$ values showed the opposite trend.

\section{Conclusions and perspectives}

This study generates an improved dataset on carbonaceous matter in the atmosphere and glaciers of the HTP, which will provide valuable reference values for other studies, such as radiative forcing estimates and modeling. Although most of the HTP is influenced by carbonaceous particles transported long distance, locally sourced carbonaceous matter from fossil fuel and biomass combustion substantially contribute to pollutants in urban cities and some remote stations, respectively. Seasonal variations of carbonaceous matter deposition in the HTP are mainly controlled by precipitation amount, with dry deposition accounting for a larger portion than estimated by models (Yan et al., 2019). Because the HTP is surrounded by high mountains at its southern and western fringes, fine particles of surface soil significantly affect the concentration, composition, and light absorption properties of carbonaceous matter of the HTP, especially in the northern and western parts where is characterized by a dry environment.

While considerable advances have been made in characterizing HTP carbonaceous particles, further research is needed. For instance, the characteristics of locally sourced carbonaceous particles should be comprehensively studied, and it is necessary to establish high-resolution emission inventories for carbonaceous particles generated from the inner HTP. Additionally, the HTP stations and glaciers that have been sampled for carbonaceous particles are primarily distributed in the 
eastern and southern regions of the HTP, and more studies need to be conducted in the western and northern regions of the HTP. Furthermore, quantities such as size distributions, morphologies, and vertical distributions of carbonaceous matter need further investigation. To produce high quality data that is representative of larger regions of the HTP, more stations with limited influence from local residents and microtopography (e.g., those located in wide areas and distant from local anthropogenic activities) should also be set up. At least three potential factors should be considered during the establishment of an "ideal" remote station: it should be in open terrain, at a suitable distance from local residents, and representative of the land type of the region. Future research that addresses these areas of research will further understanding of the sources and distribution of carbonaceous particles on the HTP, and allow a better assessment of the role of carbonaceous particles in climate change and albedo reductions in this sensitive region.

\section{Declaration of Competing Interest}

The authors declare that they have no known competing financial interests or personal relationships that could have appeared to influence the work reported in this paper.

\section{Acknowledgments}

This study is supported by the Strategic Priority Research Program of Chinese Academy of Sciences (CAS), the Pan-Third Pole Environment Study for a Green Silk Road (Pan-TPE) (XDA20040501), the second Tibetan Plateau Scientific Expedition and Research Program (STEP) (2019QZKK0605), the NSFC (41971096, 41630754, 41705132), and the State Key Laboratory of Cryospheric Science (SKLCS-ZZ-2020). This study is part of a framework across the HTP: Atmospheric Pollution and Cryospheric Change (APCC). The authors are thankful for basic meteorological data from Nam Co Station for Multisphere Observation and Research; Qomolangma Station for Atmospheric and Environmental Observation and Research; South-East Tibetan Plateau Station for integrated observation and research of alpine environment; Yulong, Qilian Shan, and Ngari Station for Desert Environment Observation and Research; and Muztagh Ata Station for Westerly Environment Observation and Research. We thank the editor and three anonymous reviewers for their constructive feedback.

\section{Appendix A. Supplementary material}

Supplementary data to this article can be found online at https://doi. org/10.1016/j.envint.2020.106281.

\section{References}

Andreae, M.O., Gelencser, A., 2006. Black carbon or brown carbon? The nature of lightabsorbing carbonaceous aerosols. Atmos. Chem. Phys. 6, 3131-3148.

Bauer, S.E., Bausch, A., Nazarenko, L., Tsigaridis, K., Xu, B., Edwards, R., Bisiaux, M., McConnell, J., 2013. Historical and future black carbon deposition on the three ice caps: Ice core measurements and model simulations from 1850 to 2100 . J. Geophys. Res.: Atmos. 118, 7948-7961.

Bikkina, S., Andersson, A., Kirillova, E.N., Holmstrand, H., Tiwari, S., Srivastava, A., Bisht, D., Gustafsson, Ö., 2019. Air quality in megacity Delhi affected by countryside biomass burning. Nat. Sustain. 2, 200.

Bond, T.C., Bergstrom, R.W., 2006. Light absorption by carbonaceous particles: an investigative review. Aerosol Sci. Technol. 40, 27-67.

Bond, T.C., Doherty, S.J., Fahey, D.W., Forster, P.M., Berntsen, T., DeAngelo, B.J., Flanner, M.G., Ghan, S., Kaercher, B., Koch, D., Kinne, S., Kondo, Y., Quinn, P.K., Sarofim, M.C., Schultz, M.G., Schulz, M., Venkataraman, C., Zhang, H., Zhang, S., Bellouin, N., Guttikunda, S.K., Hopke, P.K., Jacobson, M.Z., Kaiser, J.W., Klimont, Z., Lohmann, U., Schwarz, J.P., Shindell, D., Storelvmo, T., Warren, S.G., Zender, C.S., 2013. Bounding the role of black carbon in the climate system: a scientific assessment. J. Geophys. Res.-Atmos. 118, 5380-5552.

Bond, T.C., Habib, G., Bergstrom, R.W., 2006. Limitations in the enhancement of visible light absorption due to mixing state. J. Geophys. Res.: Atmos. 111.

Bosch, C., Andersson, A., Kirillova, E.N., Budhavant, K., Tiwari, S., Praveen, P., Russell, L.M., Beres, N.D., Ramanathan, V., Gustafsson, Ö., 2014. Source-diagnostic dual-isotope composition and optical properties of water-soluble organic carbon and elemental carbon in the South Asian outflow intercepted over the Indian Ocean. J. Geophys. Res.: Atmos. 119 (11), 743-711, 759.

Cao, J.-J., Xu, B.-Q., He, J.-Q., Liu, X.-Q., Han, Y.-M., Wang, G.-H., Zhu, C.-S., 2009. Concentrations, seasonal variations, and transport of carbonaceous aerosols at a remote Mountainous region in western China. Atmos. Environ. 43, 4444-4452.

Cerqueira, M., Pio, C., Legrand, M., Puxbaum, H., Kasper-Giebl, A., Afonso, J.,

Preunkert, S., Gelencsér, A., Fialho, P., 2010. Particulate carbon in precipitation at European background sites. J. Aerosol Sci. 41, 51-61.

Chen, B., Andersson, A., Lee, M., Kirillova, E.N., Xiao, Q., Krusa, M., Shi, M., Hu, K., Lu, Z., Streets, D.G., Du, K., Gustafsson, O., 2013. Source forensics of black carbon aerosols from China. Environ. Sci. Technol. 47, 9102-9108.

Chen, B., Bai, Z., Cui, X., Chen, J., Andersson, A., Gustafsson, O., 2017. Light absorption enhancement of black carbon from urban haze in Northern China winter. Environ. Pollut. 221, 418-426.

Chen, P., Kang, S., Bai, J., Sillanpää, M., Li, C., 2015. Yak dung combustion aerosols in the Tibetan Plateau: Chemical characteristics and influence on the local atmospheric environment. Atmos. Res. 156, 58-66.

Chen, P., Kang, S., Li, C., Zhang, Q., Guo, J., Tripathee, L., Zhang, Y., Li, G., Gul, C., Cong, Z., Wan, X., Niu, H., Panday, A.K., Rupakheti, M., Ji, Z., 2019. Carbonaceous aerosol characteristics on the Third Pole: a primary study based on the Atmospheric Pollution and Cryospheric Change (APCC) network. Environ. Pollut. (Barking, Essex 1987) 253, 49-60.

Chen, X., Kang, S., Cong, Z., Yang, J., Ma, Y., 2018. Concentration, temporal variation, and sources of black carbon in the Mt. Everest region retrieved by real-time observation and simulation. Atmos. Chem. Phys. 18, 12859-12875.

Chen, Y., Bond, T.C., 2010. Light absorption by organic carbon from wood combustion. Atmos. Chem. Phys. 10, 1773-1787.

Cheng, Y., He, K.-B., Du, Z.-Y., Engling, G., Liu, J.-M., Ma, Y.-L., Zheng, M., Weber, R.J., 2016. The characteristics of brown carbon aerosol during winter in Beijing. Atmos. Environ. 127, 355-364.

Cheng, Y., He, K.-B., Engling, G., Weber, R., Liu, J.-M., Du, Z.-Y., Dong, S.-P., 2017. Brown and black carbon in Beijing aerosol: Implications for the effects of brown coating on light absorption by black carbon. Sci. Total Environ. 599, 1047-1055.

Cheng, Y., He, K.-B., Zheng, M., Duan, F.-K., Du, Z.-Y., Ma, Y.-L., Tan, J.-H., Yang, F.-M., Liu, J.-M., Zhang, X.-L., 2011. Mass absorption efficiency of elemental carbon and water-soluble organic carbon in Beijing, China. Atmos. Chem. Phys. 11, $11497-11510$

Chow, J.C., Watson, J.G., 2002. PM2.5 carbonate concentrations at regionally representative Interagency Monitoring of Protected Visual Environment sites. J. Geophys. Res.-Atmos. 107.

Chung, C.E., Ramanathan, V., Decremer, D., 2012. Observationally constrained estimates of carbonaceous aerosol radiative forcing. Proc. Natl. Acad. Sci. 109, 11624-11629.

Cong, Z., Kang, S., Kawamura, K., Liu, B., Wan, X., Wang, Z., Gao, S., Fu, P., 2015. Carbonaceous aerosols on the south edge of the Tibetan Plateau: concentrations, seasonality and sources. Atmos. Chem. Phys. 15, 1573-1584.

Cong, Z., Kang, S., Smirnov, A., Holben, B., 2009. Aerosol optical properties at Nam Co, a remote site in central Tibetan Plateau. Atmos. Res. 92, 42-48.

Cook, J., Edwards, A., Takeuchi, N., Irvine-Fynn, T., 2016. Cryoconite: the dark biological secret of the cryosphere. Prog. Phys. Geogr. 40, 66-111.

Decesari, S., Facchini, M.C., Carbone, C., Giulianelli, L., Rinaldi, M., Finessi, E., Fuzzi, S., Marinoni, A., Cristofanelli, P., Duchi, R., 2010. Chemical composition of PM 10 and PM 1 at the high-altitude Himalayan station Nepal Climate Observatory-Pyramid (NCO-P)(5079 m asl). Atmos. Chem. Phys. 10, 4583-4596.

Dhungel, S., Kathayat, B., Mahata, K., Panday, A., 2018. Transport of regional pollutants through a remote trans-Himalayan valley in Nepal. Atmos. Chem. Phys. 18, 1203.

Dong, Z., Kang, S., Qin, D., Li, Y., Wang, X., Ren, J., Li, X., Yang, J., Qin, X., 2016. Provenance of cryoconite deposited on the glaciers of the Tibetan Plateau: new insights from Nd-Sr isotopic composition and size distribution. J. Geophys. Res. Atmos. 121, 7371-7382.

Du, Z., He, K., Cheng, Y., Duan, F., Ma, Y., Liu, J., Zhang, X., Zheng, M., Weber, R., 2014. A yearlong study of water-soluble organic carbon in Beijing II: Light absorption properties. Atmos. Environ. 89, 235-241.

Ducret, J., Cachier, H., 1992. Particulate carbon content in rain at various temperate and tropical locations. J. Atmos. Chem. 15, 55-67.

Forrister, H., Liu, J., Scheuer, E., Dibb, J., Ziemba, L., Thornhill, K.L., Anderson, B., Diskin, G., Perring, A.E., Schwarz, J.P., Campuzano-Jost, P., Day, D.A., Palm, B.B., Jimenez, J.L., Nenes, A., Weber, R.J., 2015. Evolution of brown carbon in wildfire plumes. Geophys. Res. Lett. 42, 4623-4630.

Forster, C., Wandinger, U., Wotawa, G., James, P., Mattis, I., Althausen, D. Simmonds, P., O'Doherty, S., Jennings, S.G., Kleefeld, C., 2001. Transport of boreal forest fire emissions from Canada to Europe. J. Geophys. Res.: Atmos. 106, 22887-22906.

Gautam, S., Yan, F., Kang, S., Han, X., Neupane, B., Chen, P., Hu, Z., Sillanpää, M., Li, C., 2019. Black carbon in surface soil of the Himalayas and Tibetan Plateau and its contribution to total black carbon deposition at glacial region. Environ. Sci. Pollut. Res. 1-7.

Gautam, S., Yan, F., Kang, S., Han, X., Neupane, B., Chen, P., Hu, Z., Sillanpää, M., Li, C., 2020. Black carbon in surface soil of the Himalayas and Tibetan Plateau and its contribution to total black carbon deposition at glacial region. Environ. Sci. Pollut. Res. 27, 2670-2676.

Gertler, C.G., Puppala, S.P., Panday, A., Stumm, D., Shea, J., 2016. Black carbon and the Himalayan cryosphere: a review. Atmos. Environ. 125, 404-417.

Gustafsson, Ö., Kruså, M., Zencak, Z., Sheesley, R.J., Granat, L., Engström, E., Praveen, P. S., Rao, P.S.P., Leck, C., Rodhe, H., 2009. Brown clouds over South Asia: biomass or fossil fuel combustion? Science 323, 495-498. 
Gustafsson, Ö., Ramanathan, V., 2016. Convergence on climate warming by black carbon aerosols. Proc. Natl. Acad. Sci. 113, 4243-4245.

Hallquist, M., Wenger, J.C., Baltensperger, U., Rudich, Y., Simpson, D., Claeys, M., Dommen, J., Donahue, N.M., George, C., Goldstein, A.H., Hamilton, J.F., Herrmann, H., Hoffmann, T., Iinuma, Y., Jang, M., Jenkin, M.E., Jimenez, J.L., Kiendler-Scharr, A., Maenhaut, W., McFiggans, G., Mentel, T.F., Monod, A., Prevot, A.S.H., Seinfeld, J.H., Surratt, J.D., Szmigielski, R., Wildt, J., 2009. The formation, properties and impact of secondary organic aerosol: current and emerging issues. Atmos. Chem. Phys. 9, 5155-5236.

Han, Y., Wei, C., Bandowe, B., Wilcke, W., Cao, J., Xu, B., Gao, S., Tie, X., Li, G., Jin, Z., 2015. Elemental carbon and polycyclic aromatic compounds in a 150-year sediment core from Lake Qinghai, Tibetan Plateau, China: influence of regional and local sources and transport pathways. Environ. Sci. Technol. 49, 4176-4183.

Han, Y.M., Wei, C., Huang, R.J., Bandowe, B.A.M., Ho, S.S.H., Cao, J.J., Jin, Z.D., Xu, B. Q., Gao, S.P., Tie, X.X., An, Z.S., Wilcke, W., 2016. Reconstruction of atmospheric soot history in inland regions from lake sediments over the past 150 years. Sci. Rep. 6.

He, C., Flanner, M.G., Chen, F., Barlage, M., Liou, K.-N., Kang, S., Ming, J., Qian, Y., 2018. Black carbon-induced snow albedo reduction over the Tibetan Plateau: uncertainties from snow grain shape and aerosol-snow mixing state based on an updated SNICAR model. Atmos. Chem. Phys. (Online) 18.

He, C., Li, Q., Liou, K.-N., Takano, Y., Gu, Y., Qi, L., Mao, Y., Leung, L.R., 2014. Black carbon radiative forcing over the Tibetan Plateau. Geophys. Res. Lett. 41, 7806-7813.

He, C., Liou, K.-N., Takano, Y., Zhang, R., Levy Zamora, M., Yang, P., Li, Q., Leung, L.R., 2015. Variation of the radiative properties during black carbon aging: theoretical and experimental intercomparison. 1foldr Import 2019-10-08 Batch 2.

He, C., Takano, Y., Liou, K.-N., Yang, P., Li, Q., Mackowski, D.W., 2016. Intercomparison of the GOS approach, superposition T-matrix method, and laboratory measurements for black carbon optical properties during aging. J. Quant. Spectrosc. Radiat. Transfer 184, 287-296.

Helms, J.R., Stubbins, A., Ritchie, J.D., Minor, E.C., Kieber, D.J., Mopper, K., 2008. Absorption spectral slopes and slope ratios as indicators of molecular weight, source, and photobleaching of chromophoric dissolved organic matter. Limnol. Oceanogr. 53, 955-969.

Hu, T., Cao, J., Zhu, C., Zhao, Z., Liu, S., Zhang, D., 2018a. Morphologies and elemental compositions of local biomass burning particles at urban and glacier sites in southeastern Tibetan Plateau: results from an expedition in 2010. Sci. Total Environ. 628, 772-781.

Hu, Z., Kang, S., Li, C., Yan, F., Chen, P., Gao, S., Wang, Z., Zhang, Y., Sillanpaa, M., 2017. Light absorption of biomass burning and vehicle emission-sourced carbonaceous aerosols of the Tibetan Plateau. Environ. Sci. Pollut. Res. 24, 15369-15378.

Hu, Z., Kang, S., Li, X., Li, C., Sillanpää, M., 2020. Relative contribution of mineral dust versus black carbon to Third Pole glacier melting. Atmos. Environ. 223, 117288.

Hu, Z., Kang, S., Yan, F., Zhang, Y., Li, Y., Chen, P., Qin, X., Wang, K., Gao, S., Li, C., 2018b. Dissolved organic carbon fractionation accelerates glacier-melting: a case study in the northern Tibetan Plateau. Sci. Total Environ. 627, 579-585.

Huo, M., Sato, K., Ohizumi, T., Akimoto, H., Takahashi, K., 2016. Characteristics of carbonaceous components in precipitation and atmospheric particle at Japanese sites. Atmos. Environ. 146, 164-173.

IPCC, 2013. Climate Change 2013. The Physical Science Basis. in Contribution of Working Group I to the Fifth Assessment Report of the Intergovernmental Panel on Climate Change Rep. Cambridge Univeristy. Press, Cambridge, U.K., and New York.

Ishikawa, Y., Murakami, H., Sekine, T., Yoshihara, K., 1995. Precipitation scavenging studies of radionuclides in air using cosmogenic 7Be. J. Environ. Radioact. 26, 19-36.

Ji, Z., Kang, S., Cong, Z., Zhang, Q., Yao, T., 2015. Simulation of carbonaceous aerosols over the Third Pole and adjacent regions: distribution, transportation, deposition, and climatic effects. Clim. Dyn. 45, 2831-2846.

Jurado, E., Dachs, J., Duarte, C.M., Simo, R., 2008. Atmospheric deposition of organic and black carbon to the global oceans. Atmos. Environ. 42, 7931-7939.

Kang, S., Zhang, Q., Qian, Y., Ji, Z., Li, C., Cong, Z., Zhang, Y., Guo, J., Du, W., Huang, J., 2019. Linking atmospheric pollution to cryospheric change in the third pole region: current progresses and future prospects. Natl. Sci. Rev.

Kang, S., Zhang, Y., Qian, Y., Wang, H., 2020. A review of black carbon in snow and ice and its impact on the cryosphere. Earth Sci. Rev. 103346.

Kaspari, S., Painter, T.H., Gysel, M., Skiles, S.M., Schwikowski, M., 2014. Seasonal and elevational variations of black carbon and dust in snow and ice in the Solu-Khumbu, Nepal and estimated radiative forcings. Atmos. Chem. Phys. 14, 8089-8103.

Kim, H., Kim, J.Y., Jin, H.C., Lee, J.Y., Lee, S.P., 2016. Seasonal variations in the lightabsorbing properties of water-soluble and insoluble organic aerosols in Seoul, Korea. Atmos. Environ. 129, 234-242.

Kirillova, E.N., Andersson, A., Han, J., Lee, M., Gustafsson, Ö., 2014. Sources and light absorption of water-soluble organic carbon aerosols in the outflow from northern China. Atmos. Chem. Phys. 14, 1413-1422.

Kirillova, E.N., Marinoni, A., Bonasoni, P., Vuillermoz, E., Facchini, M.C., Fuzzi, S., Decesari, S., 2016. Light absorption properties of brown carbon in the high Himalayas. J. Geophys. Res.-Atmos. 121, 9621-9639.

Kondo, Y., Sahu, L., Kuwata, M., Miyazaki, Y., Takegawa, N., Moteki, N., Imaru, J., Han, S., Nakayama, T., Oanh, N.K., 2009. Stabilization of the mass absorption cross section of black carbon for filter-based absorption photometry by the use of a heated inlet. Aerosol Sci. Technol. 43, 741-756.

Kopacz, M., Mauzerall, D.L., Wang, J., Leibensperger, E.M., Henze, D.K., Singh, K., 2011. Origin and radiative forcing of black carbon transported to the Himalayas and Tibetan Plateau. Atmos. Chem. Phys. 11, 2837-2852.
Lambe, A.T., Cappa, C.D., Massoli, P., Onasch, T.B., Forestieri, S.D., Martin, A.T., Cummings, M.J., Croasdale, D.R., Brune, W.H., Worsnop, D.R., Davidovits, P., 2013. Relationship between oxidation level and optical properties of secondary organic aerosol. Environ. Sci. Technol. 47, 6349-6357.

Lau, K.M., Kim, M.K., Kim, K.M., 2006. Asian summer monsoon anomalies induced by aerosol direct forcing: the role of the Tibetan Plateau. Clim. Dyn. 26, 855-864.

Lau, W.K.M., Kim, M.-K., Kim, K.-M., Lee, W.-S., 2010. Enhanced surface warming and accelerated snow melt in the Himalayas and Tibetan Plateau induced by absorbing aerosols. Environ. Res. Lett. 5, 025204.

Li, C., Bosch, C., Kang, S., Andersson, A., Chen, P., Zhang, Q., Cong, Z., Chen, B., Qin, D., Gustafsson, O., 2016a. Sources of black carbon to the Himalayan-Tibetan Plateau glaciers. Nat. Commun. 7, 12574.

Li, C., Chen, P., Kang, S., Yan, F., Hu, Z., Qu, B., Sillanpää, M., 2016b. Concentrations and light absorption characteristics of carbonaceous aerosol in PM2.5 and PM10 of Lhasa city, the Tibetan Plateau. Atmos. Environ. 127, 340-346.

Li, C., Chen, P., Kang, S., Yan, F., Li, X., Qu, B., Sillanpää, M., 2016c. Carbonaceous matter deposition in the high glacial regions of the Tibetan Plateau. Atmos. Environ. 141, 203-208.

Li, C., Chen, P., Kang, S., Yan, F., Tripathee, L., Wu, G., Qu, B., Sillanpaa, M., Yang, D., Dittmar, T., Stubbins, A., Raymond, P.A., 2018a. Fossil fuel combustion emission from South Asia influences precipitation dissolved organic carbon reaching the remote tibetan plateau: isotopic and molecular evidence. J. Geophys. Res.-Atmos. $123,6248-6258$.

Li, C., Kang, S., Yan, F., 2018b. Importance of local black carbon emissions to the fate of glaciers of the third pole. Environ. Sci. Technol. 52, 14027-14028.

Li, C., Yan, F., Kang, S., Chen, P., Han, X., Hu, Z., Zhang, G., Hong, Y., Gao, S., Qu, B., Zhu, Z., Li, J., Chen, B., Sillanpaa, M., 2017a. Re-evaluating black carbon in the Himalayas and the Tibetan Plateau: concentrations and deposition. Atmos. Chem. Phys. 17, 11899-11912.

Li, C., Yan, F., Kang, S., Chen, P., Hu, Z., Gao, S., Qu, B., Sillanpää, M., 2016d. Light absorption characteristics of carbonaceous aerosols in two remote stations of the southern fringe of the Tibetan Plateau, China. Atmos. Environ. 79-85.

Li, C., Yan, F., Kang, S., Chen, P., Hu, Z., Han, X., Zhang, G., Gao, S., Qu, B., Sillanpää, M., 2017b. Deposition and light absorption characteristics of precipitation dissolved organic carbon (DOC) at three remote stations in the Himalayas and Tibetan Plateau, China. Sci. Total Environ. 605, 1039-1046.

Li, X., Kang, S., He, X., Qu, B., Tripathee, L., Jing, Z., Paudyal, R., Li, Y., Zhang, Y., Yan, F., Li, G., Li, C., 2017c. Light-absorbing impurities accelerate glacier melt in the Central Tibetan Plateau. Sci. Total Environ. 587, 482-490.

Li, X., Kang, S., Zhang, G., Qu, B., Tripathee, L., Paudyal, R., Jing, Z., Zhang, Y., Yan, F., Li, G., 2018c. Light-absorbing impurities in a southern Tibetan Plateau glacier: variations and potential impact on snow albedo and radiative forcing. Atmos. Res. 200, 77-87.

Li, Y., Kang, S., Chen, J., Hu, Z., Wang, K., Paudyal, R., Liu, J., Wang, X., Qin, X., Sillanpää, M., 2019a. Black carbon in a glacier and snow cover on the northeastern Tibetan Plateau: concentrations, radiative forcing and potential source from local topsoil. Sci. Total Environ. 686, 1030-1038.

Li, Y., Kang, S.C., Yan, F.P., Chen, J.Z., Wang, K., Paudyal, R., Liu, J.S., Qin, X. Sillanpaa, M., 2019b. Cryoconite on a glacier on the north-eastern Tibetan plateau: light-absorbing impurities, albedo and enhanced melting. J. Glaciol. 65, 633-644.

Lin, H., Wang, X., Gong, P., Ren, J., Wang, C., Yuan, X., Wang, L., Yao, T., 2017. The influence of climate change on the accumulation of polycyclic aromatic hydrocarbons, black carbon and mercury in a shrinking remote lake of the southern Tibetan Plateau. Sci. Total Environ. 601, 1814-1823.

Liu, B., Cong, Z., Wang, Y., Xin, J., Wan, X., Pan, Y., Liu, Z., Wang, Y., Zhang, G., Wang, Z., Wang, Y., Kang, S., 2017. Background aerosol over the Himalayas and Tibetan Plateau: observed characteristics of aerosol mass loading. Atmos. Chem. Phys. 17, 449-463.

Marinoni, A., Cristofanelli, P., Laj, P., Duchi, R., Calzolari, F., Decesari, S., Sellegri, K., Vuillermoz, E., Verza, G.P., Villani, P., Bonasoni, P., 2010. Aerosol mass and black carbon concentrations, a two year record at NCO-P (5079 m, Southern Himalayas), Atmos. Chem. Phys. 10, 8551-8562.

Martinsson, J., Eriksson, A.C., Nielsen, I.E., Malmborg, V.B., Ahlberg, E., Andersen, C., Lindgren, R., Nystrom, R., Nordin, E.Z., Brune, W.H., Svenningsson, B. Swietlicki, E., Boman, C., Pagels, J.H., 2015. Impacts of combustion conditions and photochemical processing on the light absorption of biomass combustion aerosol. Environ. Sci. Technol. 49, 14663-14671.

Menon, S., Koch, D., Beig, G., Sahu, S., Fasullo, J., Orlikowski, D., 2010. Black carbon aerosols and the third polar ice cap. Atmos. Chem. Phys. 10, 4559-4571.

Meyer, T., Lei, Y.D., Muradi, I., Wania, F., 2008. Organic contaminant release from melting snow. 1. Influence of chemical partitioning. Environ. Sci. Technol. 43, $657-662$.

Miller, W.L., Zepp, R.G., 1995. Photochemical production of dissolved inorganic carbon from terrestrial organic matter: Significance to the oceanic organic carbon cycle. Geophys. Res. Lett. 22, 417-420.

Ming, J., Cachier, H., Xiao, C., Qin, D., Kang, S., Hou, S., Xu, J., 2008. Black carbon record based on a shallow Himalayan ice core and its climatic implications. Atmos. Chem. Phys. 8, 1343-1352.

Ming, J., Xiao, C., Du, Z., Yang, X., 2013. An overview of black carbon deposition in High Asia glaciers and its impacts on radiation balance. Adv. Water Resour. 55, 80-87.

Ming, J., Xiao, C., Sun, J., Kang, S., Bonasoni, P., 2010. Carbonaceous particles in the atmosphere and precipitation of the Nam Co region, central Tibet. J. Environ. Sci. $22,1748-1756$.

Mladenov, N., Alados-Arboledas, L., Olmo, F.J., Lyamani, H., Delgado, A., Molina, A., Reche, I., 2011. Applications of optical spectroscopy and stable isotope analyses to 
organic aerosol source discrimination in an urban area. Atmos. Environ. 45, 1960-1969.

Narukawa, M., Kawamura, K., Takeuchi, N., Nakajima, T., 1999. Distribution of dicarboxylic acids and carbon isotopic compositions in aerosols from 1997 Indonesian forest fires. Geophys. Res. Lett. 26, 3101-3104.

Niu, H., Kang, S., Shi, X., Zhang, G., Wang, S., Pu, T., 2019. Dissolved organic carbon in summer precipitation and its wet deposition flux in the Mt. Yulong region, southeastern Tibetan Plateau. J. Atmos. Chem.

Niu, H., Kang, S., Wang, H., Zhang, R., Lu, X., Qian, Y., Paudyal, R., Wang, S., Shi, X., Yan, X., 2018. Seasonal variation and light absorption property of carbonaceous aerosol in a typical glacier region of the southeastern Tibetan Plateau. Atmos. Chem. Phys. 18, 6441

Pant, P., Hegde, P., Dumka, U.C., Sagar, R., Satheesh, S.K., Moorthy, K.K., Saha, A., Srivastava, M.K., 2006. Aerosol characteristics at a high-altitude location in centra Himalayas: Optical properties and radiative forcing. J. Geophys. Res.-Atmos. 111.

Petzold, A., Ogren, J., Fiebig, M., Laj, P., Li, S.-M., Baltensperger, U., Holzer-Popp, T., Kinne, S., Pappalardo, G., Sugimoto, N., 2013. Recommendations for reporting" black carbon" measurements. Atmos. Chem. Phys. 13, 8365-8379.

Pio, C.A., Legrand, M., Oliveira, T., Afonso, J., Santos, C., Caseiro, A., Fialho, P., Barata, F., Puxbaum, H., Sanchez-Ochoa, A., Kasper-Giebl, A., Gelencser, A., Preunkert, S., Schock, M., 2007. Climatology of aerosol composition (organic versus inorganic) at nonurban sites on a west-east transect across Europe. J. Geophys. Res. Atmos. 112.

Qi, L., Wang, S., 2019. Fossil fuel combustion and biomass burning sources of global black carbon from GEOS-Chem simulation and carbon isotope measurements. Atmos. Chem. Phys. 19, 11545-11557.

Qian, Y., Flanner, M.G., Leung, L.R., Wang, W., 2011. Sensitivity studies on the impacts of Tibetan Plateau snowpack pollution on the Asian hydrological cycle and monsoon climate. Atmos. Chem. Phys. 11, 1929-1948.

Qu, B., Ming, J., Kang, S.C., Zhang, G.S., Li, Y.W., Li, C.D., Zhao, S.Y., Ji, Z.M., Cao, J.J., 2014. The decreasing albedo of the Zhadang glacier on western Nyainqentanglha and the role of light-absorbing impurities. Atmos. Chem. Phys. 14, 11117-11128.

Ram, K., Sarin, M.M., 2009. Absorption coefficient and site-specific mass absorption efficiency of elemental carbon in aerosols over urban, rural, and high-altitude sites in India. Environ. Sci. Technol. 43, 8233-8239.

Ram, K., Sarin, M.M., Hegde, P., 2010. Long-term record of aerosol optical properties and chemical composition from a high-altitude site (Manora Peak) in Central Himalaya. Atmos. Chem. Phys. 10, 11791-11803.

Ramanathan, V., Carmichael, G., 2008. Global and regional climate changes due to black carbon. Nat. Geosci. 1, 221-227.

Ramanathan, V., Crutzen, P.J., Lelieveld, J., Mitra, A., Althausen, D., Anderson, J., Andreae, M., Cantrell, W., Cass, G., Chung, C., 2001. Indian ocean experiment: an integrated analysis of the climate forcing and effects of the great Indo-Asian haze. J. Geophys. Res.: Atmos. 106, 28371-28398.

Rastogi, N., Sarin, M., 2005. Chemical characteristics of individual rain events from a semi-arid region in India: three-year study. Atmos. Environ. 39, 3313-3323.

Raymond, P.A., 2005. The composition and transport of organic carbon in rainfall: Insights from the natural $\left({ }^{13} \mathrm{C}\right.$ and $\left.{ }^{14} \mathrm{C}\right)$ isotopes of carbon. Geophys. Res. Lett. 32 , L14402.

Saleh, R., Robinson, E.S., Tkacik, D.S., Ahern, A.T., Liu, S., Aiken, A.C., Sullivan, R.C., Presto, A.A., Dubey, M.K., Yokelson, R.J., Donahue, N.M., Robinson, A.L., 2014. Brownness of organics in aerosols from biomass burning linked to their black carbon content. Nat. Geosci. 7, 647-650.

Schnaiter, M., Gimmler, M., Llamas, I., Linke, C., Jäger, C., Mutschke, H., 2006. Strong spectral dependence of light absorption by organic carbon particles formed by propane combustion. Atmos. Chem. Phys. 6, 2981-2990.

Sheesley, R.J., Schauer, J.J., Chowdhury, Z., Cass, G.R., Simoneit, B.R., 2003. Characterization of organic aerosols emitted from the combustion of biomass indigenous to South Asia. J. Geophys. Res.: Atmos. 108.

Six, D., Fily, M., Blarel, L., Goloub, P., 2005. First aerosol optical thickness measurements at Dome C (East Antarctica), summer season 2003-2004. Atmos. Environ. 39, 5041-5050.

Srinivas, B., Rastogi, N., Sarin, M., Singh, A., Singh, D., 2016. Mass absorption efficiency of light absorbing organic aerosols from source region of paddy-residue burning emissions in the Indo-Gangetic Plain. Atmos. Environ. 125, 360-370.

Srinivas, B., Sarin, M., 2013. Light absorbing organic aerosols (brown carbon) over the tropical Indian Ocean: impact of biomass burning emissions. Environ. Res. Lett. 8, 044042 .

Stubbins, A., Hood, E., Raymond, P.A., Aiken, G.R., Sleighter, R.L., Hernes, P.J., Butman, D., Hatcher, P.G., Striegl, R.G., Schuster, P., 2012. Anthropogenic aerosols as a source of ancient dissolved organic matter in glaciers. Nat. Geosci. 5, 198-201.

Szidat, S., Jenk, T.M., Gaggeler, H., Synal, H., Fisseha, R., Baltensperger, U., Kalberer, M., Samburova, V., Wacker, L., Saurer, M., 2004. Source apportionment of aerosols by ${ }^{14} \mathrm{C}$ measurements in different carbonaceous particle fractions. Radiocarbon 46, 475-484.

Takeuchi, N., 2002. Optical characteristics of cryoconite (surface dust) on glaciers: the relationship between light absorbency and the property of organic matter contained in the cryoconite. Ann. Glaciol. 34, 409-414.

Wan, X., Kang, S., Wang, Y., Xin, J., Liu, B., Guo, Y., Wen, T., Zhang, G., Cong, Z., 2015 Size distribution of carbonaceous aerosols at a high-altitude site on the central Tibetan Plateau (Nam Co Station, 4730 m a.s.l.). Atmos. Res. 153, 155-164.

Wang, M., Xu, B., Wang, N., Cao, J., Tie, X., Wang, H., Zhu, C., Yang, W., 2016. Two distinct patterns of seasonal variation of airborne black carbon over Tibetan Plateau. Sci. Total Environ. 573, 1041-1052.

Wang, Q., Cao, J., Han, Y., Tian, J., Zhu, C., Zhang, Y., Zhang, N., Shen, Z., Ni, H., Zhao, S., Wu, J., 2018. Sources and physicochemical characteristics of black carbon aerosol from the southeastern Tibetan Plateau: internal mixing enhances light absorption. Atmos. Chem. Phys. 18, 4639-4656.

Winiger, P., Barrett, T., Sheesley, R., Huang, L., Sharma, S., Barrie, L.A., Yttri, K.E., Evangeliou, N., Eckhardt, S., Stohl, A., 2019. Source apportionment of circum-Arctic atmospheric black carbon from isotopes and modeling. Sci. Adv. 5, eaau8052.

Xiao, Q., Saikawa, E., Yokelson, R.J., Chen, P., Li, C., Kang, S., 2015. Indoor air pollution from burning yak dung as a household fuel in Tibet. Atmos. Environ. 102, 406-412.

Xu, B., Cao, J., Hansen, J., Yao, T., Joswia, D.R., Wang, N., Wu, G., Wang, M., Zhao, H., Yang, W., 2009. Black soot and the survival of Tibetan glaciers. Proc. Natl. Acad. Sci. 106, 22114-22118.

Xu, B., Cao, J., Joswiak, D.R., Liu, X., Zhao, H., He, J., 2012. Post-depositional enrichment of black soot in snow-pack and accelerated melting of Tibetan glaciers. Environ. Res. Lett. 7, 014022.

Xu, J., Zhang, Q., Wang, Z., Yu, G., Ge, X., Qin, X., 2015. Chemical composition and size distribution of summertime PM 2.5 at a high altitude remote location in the northeast of the Qinghai-Xizang (Tibet) Plateau: insights into aerosol sources and processing in free troposphere. Atmos. Chem. Phys. 15, 5069-5081.

Xu, Y., Ramanathan, V., Washington, W., 2016. Observed high-altitude warming and snow cover retreat over Tibet and the Himalayas enhanced by black carbon aerosols. Atmos. Chem. Phys. 16, 1303-1315.

Yan, C., Zheng, M., Sullivan, A.P., Bosch, C., Desyaterik, Y., Andersson, A., Li, X., Guo, X., Zhou, T., Gustafsson, Ö., Collett Jr, J.L., 2015. Chemical characteristics and lightabsorbing property of water-soluble organic carbon in Beijing: biomass burning contributions. Atmos. Environ. 121, 4-12.

Yan, F., He, C., Kang, S., Chen, P., Hu, Z., Han, X., Gautam, S., Yan, C., Zheng, M., Sillanpää, M., 2019. Deposition of organic and black carbon: direct measurements at three remote stations in the Himalayas and Tibetan Plateau. J. Geophys. Res.: Atmos.

Yan, F., Kang, S., Sillanpää, M., Hu, Z., Gao, S., Chen, P., Gautam, S., Reinikainen, S.-P., Li, C., 2020a. A new method for extraction of methanol-soluble brown carbon: Implications for investigation of its light absorption ability. Environ. Pollut. 114300.

Yan, F., Wang, P., Kang, S., Chen, P., Hu, Z., Han, X., Sillanpää, M., Li, C., 2020b. High particulate carbon deposition in Lhasa-a typical city in the Himalayan-Tibetan Plateau—due to local contributions. Chemosphere 125843.

Yan, G., Kim, G., 2012. Dissolved organic carbon in the precipitation of Seoul, Korea: Implications for global wet depositional flux of fossil-fuel derived organic carbon. Atmos. Environ. 59, 117-124.

Yan, J., Wang, X., Gong, P., Wang, C., Cong, Z., 2018. Review of brown carbon aerosols: recent progress and perspectives. Sci. Total Environ. 634, 1475-1485.

Yao, T., Masson-Delmotte, V., Gao, J., Yu, W., Yang, X., Risi, C., Sturm, C., Werner, M., Zhao, H., He, Y., 2013. A review of climatic controls on 8180 in precipitation over the Tibetan Plateau: Observations and simulations. Rev. Geophys. 51, 525-548.

Yao, T., Thompson, L.G., Mosbrugger, V., Zhang, F., Ma, Y., Luo, T., Xu, B., Yang, X., Joswiak, D.R., Wang, W., 2012. Third pole environment (TPE). Environ. Dev. 3, 52-64.

Yasunari, T.J., Tan, Q., Lau, K.M., Bonasoni, P., Marinoni, A., Laj, P., Menegoz, M., Takemura, T., Chin, M., 2013. Estimated range of black carbon dry deposition and the related snow albedo reduction over Himalayan glaciers during dry pre-monsoon periods. Atmos. Environ. 78, 259-267.

Yin, X., Kang, S., de Foy, B., Cong, Z., Luo, J., Zhang, L., Ma, Y., Zhang, G., Rupakheti, D., Zhang, Q., 2017. Surface ozone at Nam Co in the inland Tibetan Plateau: variation, synthesis comparison and regional representativeness. Atmos. Chem. Phys. 17.

Zhang, L., Gong, S., Padro, J., Barrie, L., 2001. A size-segregated particle dry deposition scheme for an atmospheric aerosol module. Atmos. Environ. 35, 549-560.

Zhang, M., Zhao, C., Cong, Z., Du, Q., Xu, M., Chen, Y., Chen, M., Li, R., Fu, Y., Zhong, L., Kang, S., Zhao, D., Yang, Y., 2020. Impact of topography on black carbon transport to the southern Tibetan Plateau during the pre-monsoon season and its climatic implication. Atmos. Chem. Phys. 20, 5923-5943.

Zhang, R., Wang, H., Qian, Y., Rasch, P.J., Easter, R.C., Ma, P.L., Singh, B., Huang, J. Fu, Q., 2015a. Quantifying sources, transport, deposition, and radiative forcing of black carbon over the Himalayas and Tibetan Plateau. Atmos. Chem. Phys. 15, 6205-6223.

Zhang, X., Lin, Y.-H., Surratt, J.D., Weber, R.J., 2013. Sources, composition and absorption angstrom exponent of light-absorbing organic components in aeroso extracts from the Los Angeles Basin. Environ. Sci. Technol. 47, 3685-3693.

Zhang, X., Ming, J., Li, Z., Wang, F., Zhang, G., 2017a. The online measured black carbon aerosol and source orientations in the Nam Co region, Tibet. Environmental science and pollution research international.

Zhang, Y.-L., Huang, R.-J., El Haddad, I., Ho, K.-F., Cao, J.-J., Han, Y., Zotter, P., Bozzetti, C., Daellenbach, K., Canonaco, F., 2015b. Fossil vs. non-fossil sources of fine carbonaceous aerosols in four Chinese cities during the extreme winter haze episode of 2013. Atmos. Chem. Phys. 15, 1299-1312.

Zhang, Y., Kang, S., 2017. Research progress of light-absorbing impurities in glaciers of the Tibetan Plateau and its surroundings. Chin. Sci. Bull. 62, 4151-4162.

Zhang, Y., Kang, S., Cong, Z., Schmale, J., Sprenger, M., Li, C., Yang, W., Gao, T., Sillanpää, M., Li, X., 2017b. Light-absorbing impurities enhance glacier albedo reduction in the southeastern Tibetan Plateau. J. Geophys. Res. Atmos.

Zhang, Y., Xu, J., Shi, J., Xie, C., Ge, X., Wang, J., Kang, S., Zhang, Q., 2017c. Light absorption by water-soluble organic carbon in atmospheric fine particles in the central Tibetan Plateau. Environ. Sci. Pollut. Res. 24, 21386-21397.

Zhao, S., Ming, J., Sun, J., Xiao, C., 2013a. Observation of carbonaceous aerosols during 2006-2009 in Nyainqntanglha Mountains and the implications for glaciers. Environ. Sci. Pollut. Res. 20, 5827-5838.

Zhao, S., Ming, J., Xiao, C., Sun, W., Qin, X., 2012. A preliminary study on measurements of black carbon in the atmosphere of northwest Qilian Shan. J. Environ. Sci. 24, 152-159. 
Zhao, Z., Cao, J., Shen, Z., Xu, B., Zhu, C., Chen, L.W.A., Su, X., Liu, S., Han, Y., Wang, G., Ho, K., 2013b. Aerosol particles at a high-altitude site on the Southeast Tibetan Plateau, China: implications for pollution transport from South Asia. J. Geophys. Res.-Atmos. 118, 11360-11375.

Zhao, Z., Wang, Q., Xu, B., Shen, Z., Huang, R., Zhu, C., Su, X., Zhao, S., Long, X., Liu, S., Cao, J., 2017. Black carbon aerosol and its radiative impact at a high-altitude remote site on the southeastern Tibet Plateau. J. Geophys. Res.: Atmos. 122, 5515-5530.
Zhao, Z.Z., Cao, J.J., Shen, Z.X., Huang, R.J., Hu, T.F., Wang, P., Zhang, T., Liu, S.X., 2015. Chemical composition of PM2.5 at a high-altitude regional background site over Northeast of Tibet Plateau. Atmos. Pollut. Res. 6, 815-823.

Zhu, C.-S., Cao, J.-J., Xu, B.-Q., Huang, R.-J., Wang, P., Ho, K.-F., Shen, Z.-X., Liu, S.-X., Han, Y.-M., Tie, X.-X., 2016. Black carbon aerosols at Mt. Muztagh Ata, a highaltitude location in the western Tibetan Plateau. Aerosol Air Qual. Res. 16, 752-763. 